Permeability of Covers Over Low-Level Radioactive-Waste Burial Trenches, West Valley, Cattaraugus County,

New York

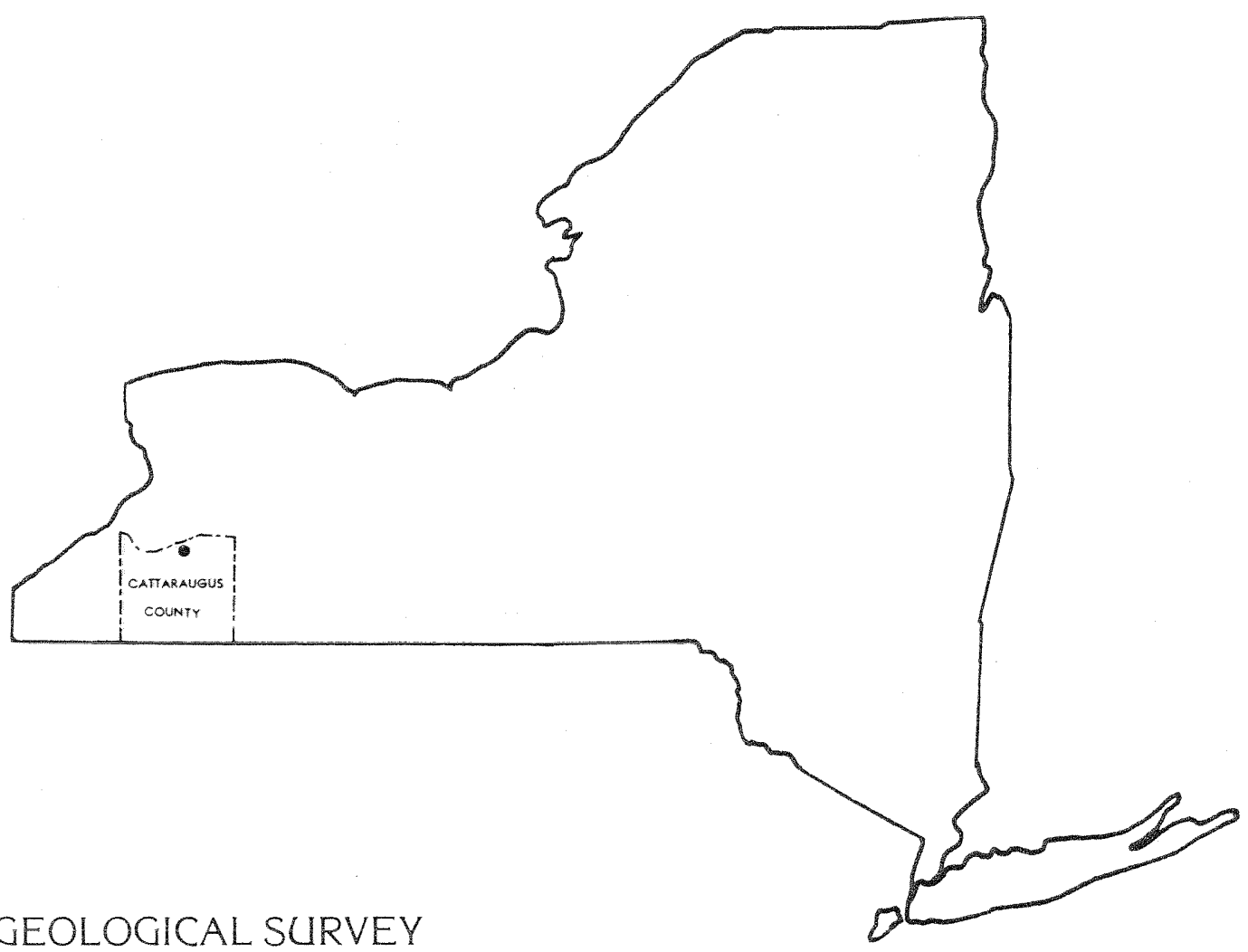

U.S. GEOLOGICAL SURVEY

Water-Resources Investigations $\quad 80-55$ 



\begin{tabular}{|c|c|c|}
\hline $\begin{array}{l}\text { PEPORT DOCUMENTATION } \\
\text { PAGE }\end{array}$ & 1. REPORT NO. & 3. Recipiant's Accrssion No. \\
\hline \multirow{2}{*}{\multicolumn{2}{|c|}{$\begin{array}{l}\text { 4. Tite and Subritle } \\
\text { Permeability of covers over low-level radioactive-waste } \\
\text { burial trenches, West Valley, New York }\end{array}$}} & $\begin{array}{l}\text { Peport Date } \\
\text { September } 1980\end{array}$ \\
\hline & & 6. \\
\hline \multicolumn{2}{|l|}{$\begin{array}{l}\text { 7. Author(s) } \\
\text { David E. Prudic }\end{array}$} & $\begin{array}{l}\text { 8. Performing Orananization Rept. No. } \\
\text { USGS/WRI } 80-55\end{array}$ \\
\hline \multirow{2}{*}{\multicolumn{2}{|c|}{$\begin{array}{l}\text { 9. Performing Organization Name and Address } \\
\text { U.S. Geological Survey } \\
\text { Water Resources Division } \\
343 \text { U. S. Post Office \& Courthouse } \\
\text { Albany, New York } 12201\end{array}$}} & 10. Project/Task/Work Unit No. \\
\hline & & $\begin{array}{l}\text { 11. Contract(C) or Granti(G) No. } \\
\text { (C) } \\
\text { (G) }\end{array}$ \\
\hline \multirow{2}{*}{\multicolumn{2}{|c|}{$\begin{array}{l}\text { 12. Sponsoring Organization Name and Address } \\
\text { U.S. Geological Survey } \\
\text { Water Resources Division } \\
343 \text { U.S. Post Office \& Courthouse } \\
\text { Albany, New York } 12201\end{array}$}} & $\begin{array}{l}\text { 13. Type of Report : Period Covered } \\
\text { Final, } 1977-78\end{array}$ \\
\hline & & 14. \\
\hline
\end{tabular}

15. Suppiementary Notes

16. Abstract (Limit: 200 words)

Gas pressure in the unsaturated parts of radioactive waste burial trenches responds to fluctuations in atmospheric pressure. Measurements of atmospheric pressure and the differential pressure between the trench gas and the atmosphere on several dates in 1977-78 were used to calculate hydraulic conductivity of the reworked silty-clay till that covers the trenches. Generally the hydraulic conductivity of covers over trenches that had a history of rapidly rising water levels are higher, at least seasonally, than covers over trenches in which the water level remained low. This supports the hypothesis that recharge occurs through the cover, presumably through fractures caused by desiccation and (or) subsidence.

Hydraulic conductivities of the cover as calculated from gas- and air-pressure measurements at several trenches were 100 to 1,000 times greater than those calculated from the increase in water levels in the trenches. This difference suggests that the values obtained from the air- and gas-pressure measurements need to be adjusted and at present are not directly usable in ground-water flux calculations. The difference in magnitude of values may be caused by rapidly decreasing hydraulic conductivity during periods of recharge or by the clogging of fractures with sediment washed in by runoff.

17. Document Analysis a. Descriptors

Infiltration; Recharge; Permeability, Water-level fluctuations; Hydraulic conductivity.

b. Identifiers/Open-Ended Terms

Radioactive waste; West Valley, N.Y.; Cattaraugus County; Burial trenches; Trench cover; Water-level rise.

c. COSATI Fieid/Group

18. Availability Statemen:

No restriction on distribution.

A. $\quad$ 19. Security Class (This Report) Unclassified

20. Security Class (This Page) Unclassified
See instructions on Revarse
21. No. of Pages 41 22. Price OPTIONAL FORA $272(4-77)$ (Formerly NTIS-35) Department of Commerco 

PERMEABILITY OF COVERS OVER LOW-LEVEL RADIOACTIVE-WASTE

BURIAL TRENCHES, WEST VALLEY, CATTARAUGUS COUNTY,

NEW YORK

by David E. Prudic

U.S. GEOLOGICAL SURVEY

Water Resources Investigations 80-55

Albany, New York

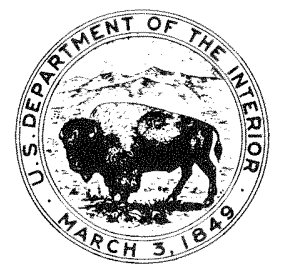

1980 


\section{UNITED STATES DEPARTMENT OF THE INTERIOR \\ CECIL D. ANDRUS, Secretary}

GEOLOGICAL SURVEY

H. William Menard, Director

For additional information write to:

U.S. Geological Survey

P.O. Box 1350

A1bany, New York 12201

(518) 472-3107 


\section{CONTENTS}

Page

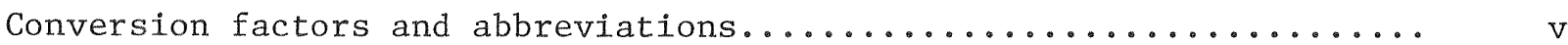

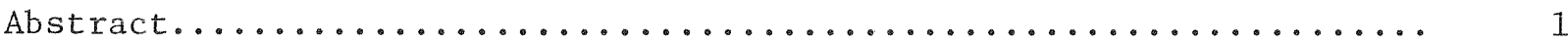

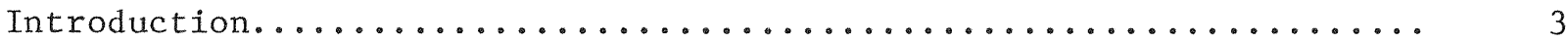

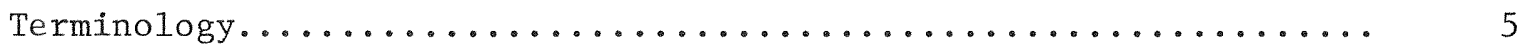

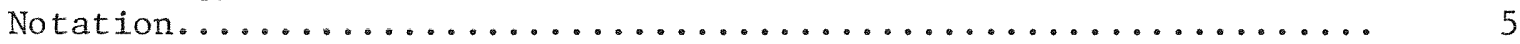

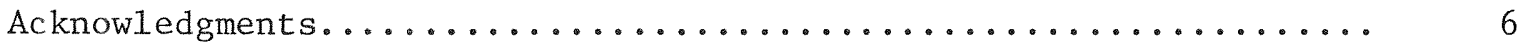

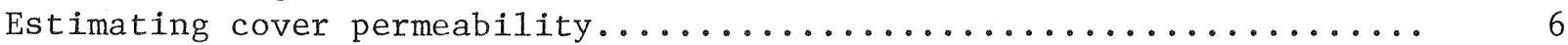

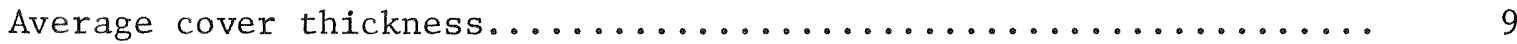

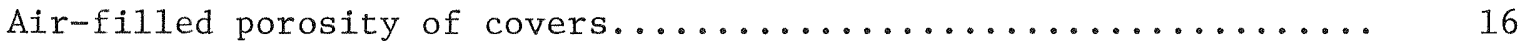

Thickness, hydraulic conductivity, and air-filled

porosity of buried waste........................... 16

Kinematic viscosity of water and dynamic viscosity of air....... 17

Errors in converting air permeability to hydraulic conductivity... 21

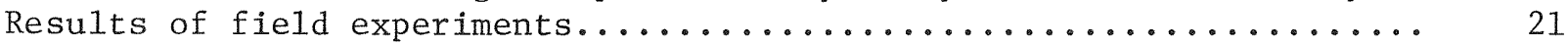

Hydraulic-conductivity differences among trenches............. 28

Relation of cracks in covers to changes in hydraulic conductivity. 28

Calculation of hydraulic conductivity from water-level rise in

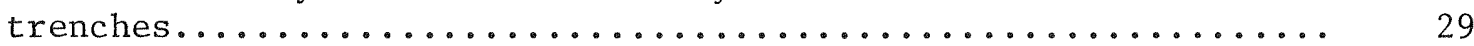

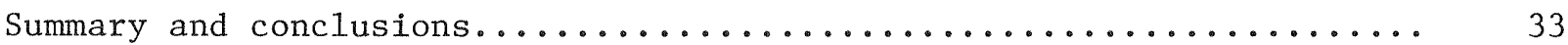

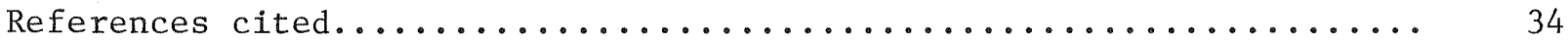

\section{ILLUSTRATIONS}

Figure 1.--Map showing layout of trenches and location of wells used to monitor trench-gas pressure in trenches at low-level radioactive-waste burial site..............

2.--Sketch of slant-tube manometer attached to a $1 \frac{1}{4}$-inch

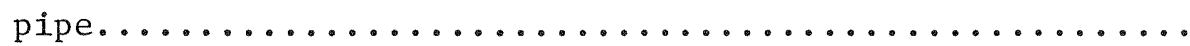

3-5.--Diagrams showing:

3.--Cross section of trench 5 at we11 series $5-3 \ldots \ldots \ldots$

4.--Cross section of trench 8 at we11 series $8-1 \ldots \ldots$

5.--Cross section of trench 14 at well series $14-1 \ldots \ldots$

6-7.--Graphs showing changes in calculated hydraulic conductivity of trench 12 cover in response to changes in:

6.--Hydraulic conductivity and air-filled porosity

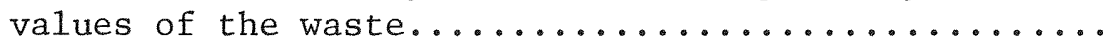

7.--Dynamic viscosity of air and kinematic viscosity

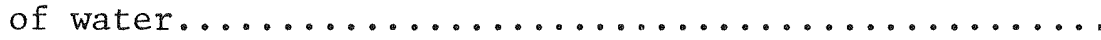




\section{ILLUSTRATIONS (Continued)}

8-12.--Graphs showing comparison of air pressures measured in selected trenches with best fitting computer simulations :

8.--Trenches 4 and 12, July 29, 1977.............. 22

9.--Trenches 5 and 14 , October $25,1977 \ldots \ldots \ldots \ldots \ldots \ldots$

10.--Trenches 3 and 12, February 9, 1978............. 24

11.--Trenches 4 and 14, Apri1 6, 1978.............. 25

12.--Trenches 4 and 12 , July $16,1978 \ldots \ldots \ldots \ldots \ldots \ldots \ldots \ldots$

\section{TABLES}

Table 1.--Estimates of cover thickness over selected low-1eve1

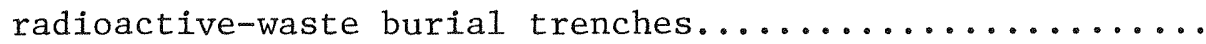

2.--Values of trench-waste and trench-cover properties used to calculate hydraulic conductivity from air-pressure

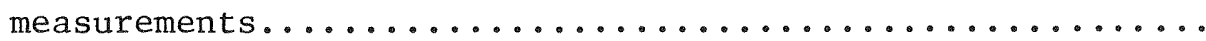

3.--Hydraulic-conductivity values calculated from airpermeability values of selected trenches..............

4.--Hydraulic conductivity of selected trench covers, as

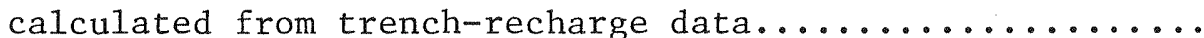




\section{CONVERSION FACTORS AND ABBREVIATIONS}

The following factors may be used to convert inch-pound units of measurement in this report to International Systems (SI) units.

Multiply inch-pouna

inch (in.)
foot (ft)
mile (mi)
square inch $\left(\mathrm{in}^{2}\right)$
square foot $\left(\mathrm{ft}^{2}\right)$
acre

inch of mercury

Darcy

feet per day (ft/day)

degree Fahrenheit $\left({ }^{\circ} \mathrm{F}\right)$
0.3048

Temperature

by

Length

2.540

0.3048

1.609

Area

6.452

929.03

0.405

\section{Pressure}

34.53

33.86

2.54

$3.386 \times 10^{4}$

Permeability

$0.987 \times 10^{-8}$

Hydraulic Conductivity

$-32 . \times 0.555$
To obtain SI units

centimeters $(\mathrm{cm})$

meter (m)

kilometers $(\mathrm{km})$

square centimeters $\left(\mathrm{cm}^{2}\right)$ square centimeters $\left(\mathrm{cm}^{2}\right)$ hectares (ha)

centimeters of water millibars

centimeters of mercury

dynes per square centimeter

square centimeters

meters per day $(\mathrm{m} / \mathrm{d})$

degree centigrade $\left({ }^{\circ} \mathrm{C}\right)$ 



\title{
PERMEABILITY OF COVERS OVER LOW-LEVEL RADIOACTIVE-WASTE BURIAL TRENCHES, WEST VALLEY, CATTARAUGUS COUNTY, NEW YORK
}

By

\author{
David E. Prudic
}

\begin{abstract}
Gas pressure in the unsaturated parts of radioactive waste-burial trenches respond to fluctuations in atmospheric pressure. Measurements of atmospheric pressure and the differential pressure between the trench gas and the atmosphere on several dates in 1977-78 were used to calculate hydraulic conductivity of the reworked silty-clay till that covers the trenches.
\end{abstract}

Generally, the hydraulic conductivity of covers over trenches that had a history of rapidly rising water levels is higher, at least seasonally, than that of covers over trenches in which the water level remained low. This supports the hypothesis that recharge occurs through the cover, presumably through fractures caused by desiccation and(or) subsidence of the cover.

Hydraulic conductivities of the covers, as calculated from gas- and air-pressure measurements at several trenches, were 100 to 1,000 times greater than those calculated from the increase in water levels in the trenches. This difference suggests that the values obtained from the air- and gas-pressure measurements need to be adjusted and are at present not directly usable in ground-water-flux calculations. The difference in magnitude of values may be caused by a rapid decrease in hydraulic conductivity during periods of recharge or by the clogging of fractures with sediment washed in by runoff.

Although the values calculated from air- and gas-pressure measurements are only relative, the method seems suitable for monitoring temporal changes in the hydraulic conductivity of a cover and for comparing hydraulic conductivity of trench covers of differing composition and structure. 



\section{INTRODUCTION}

Among the facilities at the Western New York Nuclear Service Center, near the hamlet of West Valley in the northern part of Cattaraugus County, is a state-licensed burial ground for commercial low-level radioactive wastes. The 11-acre burial ground contains a series of trenches (fig. 1) excavated in a silty-clay till of low permeability that contains scattered pods of silt, sand, and gravel. A typical trench is about 20 feet deep, 35 feet wide, and 600 to 700 feet long. Trenches 1-5 were filled in sequence from November 1963 to February 1969, and trenches 8-14 were filled in sequence from February 1969 to May 1975. (Trenches 6 and 7 were set aside for burial of special material of high specific activity.)

The U.S. Geological Survey has been investigating several low-level radioactive-waste burial grounds within the Nation to determine the factors that control the subsurface migration of radioisotopes. In addition, the New York State Geological Survey, as lead agency under contract with the U.S. Environmental Protection Agency and the Nuclear Regulatory Commission, is responsible for evaluating all processes of radioisotope migration at the West Valley site. Many elements of the two studies have required the same information, and several of these elements were jointly planned and completed by the two Surveys. One such element was the initial installation of wells used to monitor pressure differences between trench gas and the atmosphere.

Some water from precipitation that entered the trenches as they were excavated and filled with waste remained as standing water in the trenches after emplacement of the covers. After the summer of 1971, the level of this water in several of the older (north) trenches began a persistent rise and, by March 1975, had risen into the cover and began to seep out along the west side of trench 5 and the north end of trench 4 (Prudic and Randa11, 1979, p. 862). In all but one (trench 14) of the seven newer (south) trenches, water levels remained relatively constant until the autumn of 1978, when water began to rise in three of them (Prudic, 1979a).

Several investigators have concluded that the water-level rises in some trenches have been due largely to infiltration of precipitation through the covers and that differences in cover permeabilities between the north and south trenches caused the differences in water-level trends in the trenches (Matuszek and others, 1976; Giardina and others, 1977; Kelleher, 1979; and Prudic and Randa11, 1979, p. 866).

The work described in this report was done to determine whether a new technique based on the response of gas pressure in unsaturated, undisturbed soils (Weeks, 1978) could be used to evaluate the permeability of the trenchcover material and give evidence to support the postulated differences in cover permeability between the north and south trenches. 


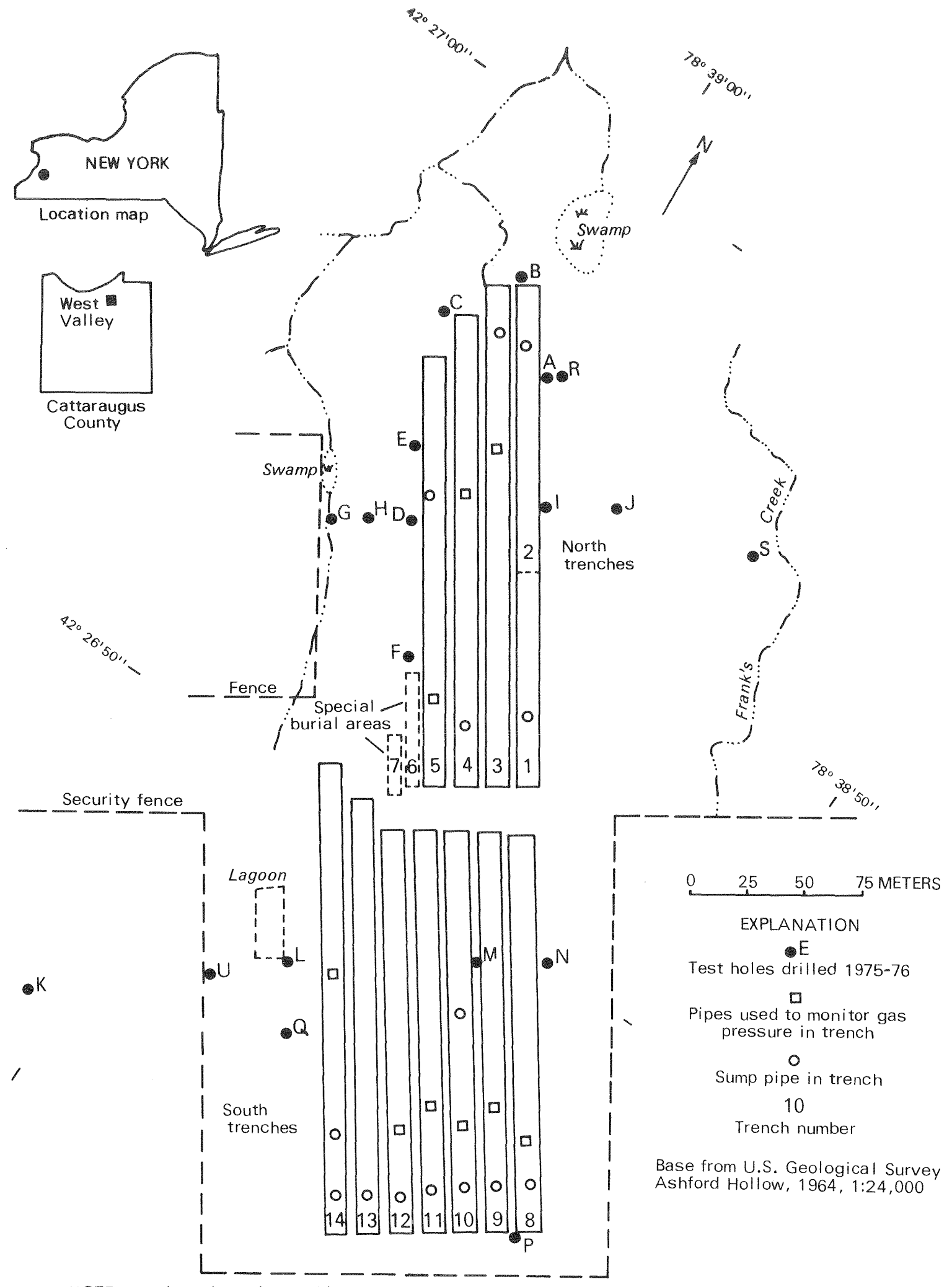

NOTE: Map based on plane-table survey by R.J. Martin, U.S. Geological Survey, 1975-78

Figure 1.--Layout of trenches and location of wells used to monitor trench-gas pressure in tienches at low-level radioactivewaste burial site, West Valley, N.Y. 


\section{Terminology}

The terminology used in this report is the same as that given by Weeks (1978, p. 2). The term "air permeability" refers to the intrinsic permeability of the porous medium as measured with alr or another gas. The term "hydraulic conductivity" is used to describe the permeability of the porous medium to water and is dependent on the kinematic viscosity of water at the prevalling temperatures and the properties of the medium. The term "air-filled porosity" refers to the amount of pores in the medium that are filled with air or another gas. The term "effective porosity" refers to the amount of interconnected pores that allow fluid transmission.

\section{Notation}

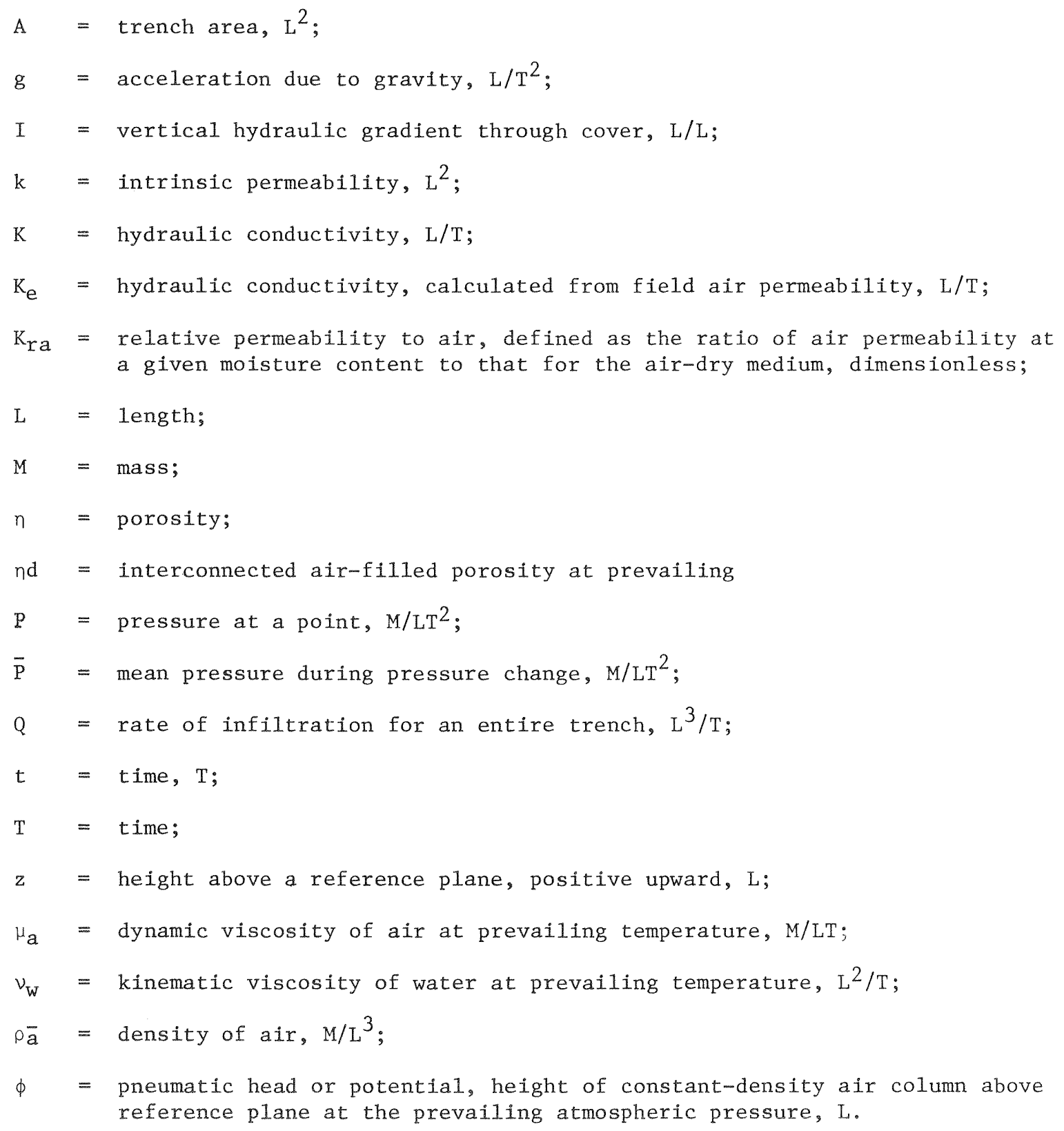




\section{Acknowledgments}

Much of the work described in this report was suggested and encouraged by Edwin P. Weeks and Allan D. Randall (U.S. Geological Survey) and Warren W. Wood (formerly with the U.S. Geological Survey). Assistance in the data collection was provided by Robert Wozniak (New York State Department of Environmental Conservation), Stephen Molello (New York State Geological Survey), and Alan Lu (formerly with New York State Department of Health).

\section{ESTIMATING COVER PERMEABILITY}

A technique developed by Weeks (1978) for estimating the vertical hydraulic conductivity of unsaturated soil under undisturbed field conditions was adapted to conditions at the burial ground. Pressure differences between the atmosphere and gas within a trench were measured during changes in atmospheric pressure. These data, along with estimated values of certain trench-cover and buried-waste properties, were read into a one-dimensional finite-difference computer program (Weeks, 1978) that calculated an air permeability at the prevailing moisture content of the trench cover and converted this to a value of hydraulic conductivity.

The equation used to calculate air permeability may be written as follows (Weeks, 1978, p. 4, eq. 3):

$$
\frac{\partial^{2} \phi}{\partial z^{2}}=\frac{\mu_{a} n_{d}}{K_{r a} k \bar{P}} \cdot \frac{\partial \phi}{\partial t}
$$

Where $\phi=$ pneumatic head, equal to $\left(P / \rho_{a} g\right)+z$;

$$
\begin{aligned}
\mu_{\mathrm{a}}= & \text { absolute } \mathrm{viscosity} \text { of air at prevailing temperature, } \mathrm{M} / \mathrm{LT} ; \\
n_{\mathrm{d}}= & \text { interconnected air-filled porosity at prevailing moisture } \\
& \text { content; } \\
\mathrm{k}= & \text { intrinsic permeability, } \mathrm{L}^{2} ; \\
\mathrm{P}= & \text { pressure at a point, } \mathrm{M} / \mathrm{LT}^{2} ; \\
\overline{\mathrm{P}}= & \text { mean pressure during pressure change, }{\mathrm{M} / \mathrm{LT}^{2} ;}^{2} \\
\mathrm{~K}_{\mathrm{ra}}= & \text { ratio of air permeability at prevailing moisture content } \\
& \text { to that of dry medium; } \\
\rho_{\mathrm{a}}= & \text { density of air, } \mathrm{M} / \mathrm{L}^{3} ; \\
\mathrm{g}= & \text { acceleration due to gravity, } \mathrm{L} / \mathrm{T}^{2} ; \\
t= & \text { time, } \mathrm{T} \text {; and } \\
\mathrm{z}= & \text { height above a reference plane, } \mathrm{L} \text { (positive upward). }
\end{aligned}
$$


The equation to convert air permeability to hydraulic conductivity may be written as follows (Weeks, 1978, p. 10):

$$
\mathrm{K}_{\mathrm{e}}=\frac{\mathrm{K}_{\mathrm{ra}} \mathrm{kg}}{\nu_{\mathrm{w}}}
$$

where $K_{e}=$ hydraulic conductivity, calculated from field air permeability, L/T;

and

$\nu_{W}=$ kinematic viscosity of water, $\mathrm{L}^{2} / \mathrm{T}$, at the prevailing temperature.

The boundary conditions used in the computer program adapted for this study (Weeks, 1978, p. 4) assume that atmospheric pressure can vary with time at 1 and surface and that gas cannot flow across the water table at depth. The program can simulate as many as six layers, each with a different permeability and air-filled porosity. Both permeability and air-filled porosity are assumed uniform throughout each layer. Also, the program specifies that the flux of gas or air from one layer equals the flux into the adjoining layer and that the air pressure is the same in two adjacent layers at their common boundary.

The program represents the trenches as two layers (waste and cover) and assumes the following conditions:

1. Movement of air through the trench cover is vertical. (This is logical because any pressure change would be uniform across the entire trench cover.)

2. The buried waste has much greater hydraulic conductivity and permeability to air than the cover. (This has been generally confirmed by the response of water leve1 to pumping of water from the trenches.)

3. Gas pressure is uniform throughout the unsaturated part of the waste at any given time. (Measurements in one trench at different depths and in two trenches at different locations [Lu and Matuszek, 1978] suggest this to be approximately true.)

4. The cover of any given trench is uniform in thickness and permeability. (Neither is true; hence calculations yield an average hydraulic conductivity that is applicable only to the trench as a whole. Therefore, no distinction was made between air permeability through fractures and through pores, even though the permeability, as measured by this technique, is probably controlled mostly by fractures.)

5. Density differences between the air and trench gas are negligible. (Scant data suggest that gas in the north trenches is roughly 6 percent less dense than air, whereas gas in the south trenches is 2 percent more dense than air [Charles Knuz, New York State Department of Health, written commun., 1979].)

6. Gas pressures generated from decaying waste within a trench are minimal compared to the pressure differences caused by fluctuations in atmospheric pressure. (Only small pressure differences, both 
negative and positive, were observed between the trench gas and the atmosphere during stable atmospheric conditions. These values were generally only 1 percent as large as pressure differences observed during changes in atmospheric pressure. In addition, results of a study by Lu and Matuszek (1978) in which gas production was accounted for were similar to those obtained in this report assuming no gas production. [See "Results of Field Experiments," page 21.])

Differential gas-pressure measurements were made with two 30 -inch slanttube manometers filled with fluid of a specific gravity of 1.20 and attached to selected $1 \frac{1}{4}$-inch pipes that had been driven into the trenches. Gas could enter the bottom of each pipe through a well point 1.5 to 3 feet long (Prudic, 1978). Manometers were attached to a pipe tapping one of the north trenches and one of the south trenches. All remaining access wells or pipes in the trenches being tested were sealed. A sketch of a manometer attached to a $1 \frac{1}{4}$-inch pipe is shown in figure 2.

The differences between atmospheric and trench-gas pressure were determined by substracting (a) the height of the liquid column in the manometer with both ends open to the atmosphere (a zero or base reading) from (b) the

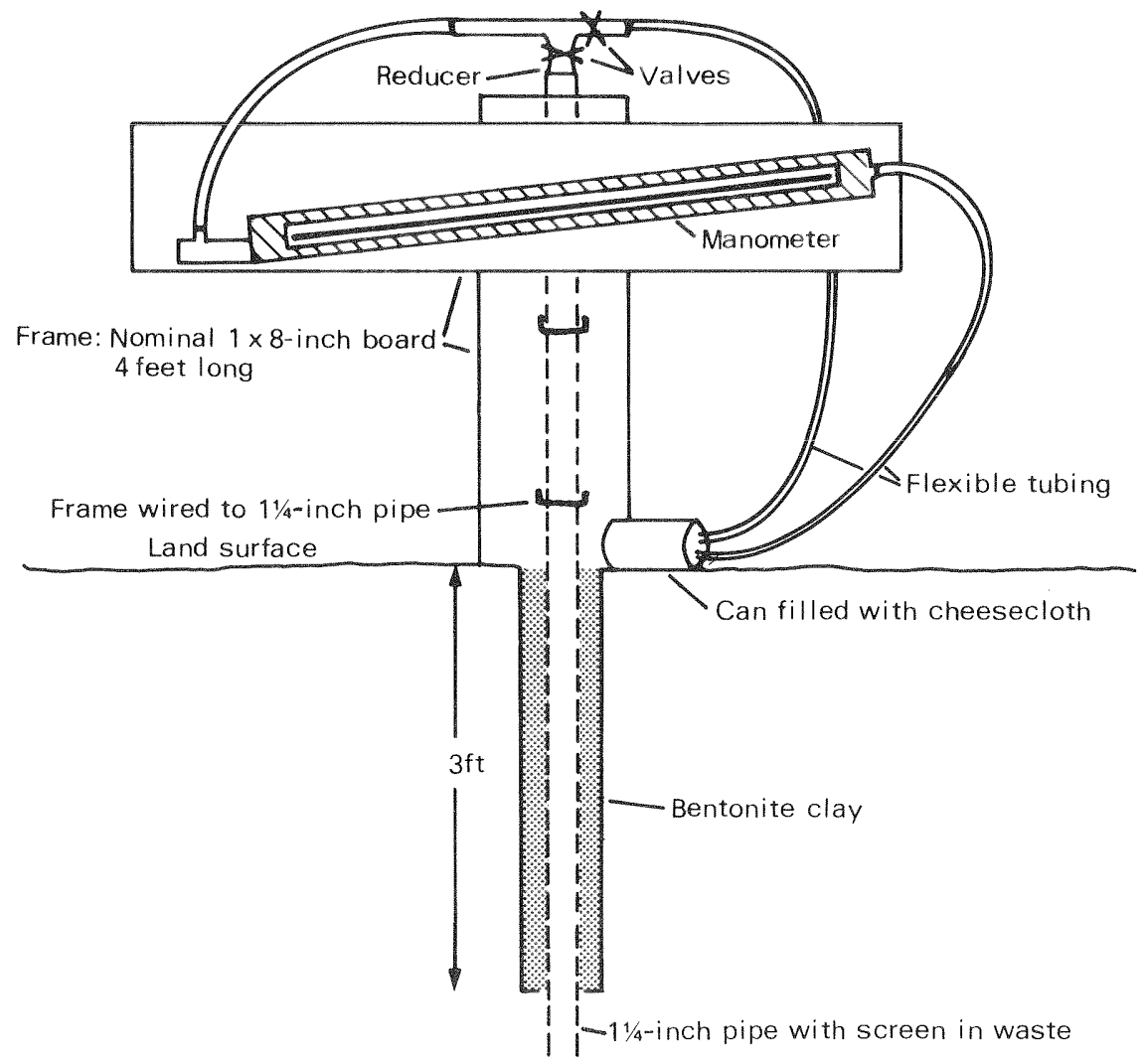

Figure 2.--Sketch of slant-tube manometer attached to a $1 \frac{1}{4}$-inch pipe. 
height of the liquid column with the lower end of the manometer connected to the $1 \frac{1}{4}$-inch pipe and the upper end open to the atmosphere. The resulting value is a pressure differential in terms of fluid head.

Atmospheric pressure was measured by a recording barograph with scale divisions of 15 minutes and 0.02 inch of mercury and later also by a portable microbarometer readable to 0.001 inch of mercury. Normally, pressure differences were read at 10- to 20-minute intervals during the normal afternoon barometric decline. On a few occasions, pressure differences were measured during the passage of a storm. Wind-caused fluctuations in the manometer fluid were reduced by extending tubing from both air-outlet ports into a can stuffed with cheesecloth near ground level (fig. 2).

Values for each of the following properties are needed to calculate the permeability of the trench covers to air and water:

1. average cover thickness

2. air-filled porosity of cover

3. depth to water in trench

4. air-filled porosity of buried waste

5. hydraulic conductivity of buried waste

6. dynamic viscosity of air and kinematic viscosity of water at prevailing temperature

The method(s) used to estimate each cover and trench property, and the sensitivity of the calculated hydraulic conductivity to each property, are described in the following sections.

\section{Average Cover Thickness}

Estimates of average thickness of trench cover were difficult to obtain, particularly for the north trenches, where records of trench construction were poor. Estimates were derived by comparing several kinds of information.

First, topographic maps were compiled before and after trench construction were compared. This was more useful in the newer (south) trenches, where the land-surface configuration was mapped just before trench construction. A preexcavation topographic map of the north trenches was also available, but the fragmentary records do not reveal whether the topsoil and surface irregularities in this area were scraped away before trench construction. Hence, estimates of cover thickness in the older trenches are suspected of being in error. These estimates might indicate the minimum thickness, however, because even though waste was reportedly piled approximately to land surface, it must have become compacted to some extent as the cover was added and before the final grade was established. 
Second, records of the cover and trench materials' resistance to pene-

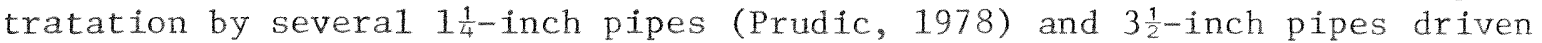
into the trench wastes (Prudic, 1979b) were examined. In general, the resistance in the older (north) trenches increased gradually to a peak between 5 and $8 \mathrm{ft}$ below land surface and was followed either by a marked decrease (11 cases) or a brief, small decrease ( 5 cases), with erratic change from then on. At the newer (south) trenches, resistance to the $1 \frac{1}{4}$-inch pipes generally became erratic below a depth of 9 to $12 \mathrm{ft}$. Abrupt changes in penetration rates were interpreted as a reflection of the variable composition of waste. At trench 14, the cover resistance was less than at the other south trenches, which may indicate less compaction of the trench 14 cover.

Third, the cover thickness was estimated from the point at which trench gas was detected as the $1 \frac{1}{4}$-inch pipes were driven into the trench wastes (Prudic, 1978). Gas was first detected a few feet below the point at which the resistance to penetration became erratic; this depth was interpreted as the maximum cover thickness. Perhaps the zone of erratic penetration just above the depth where gas was detected is cover material that has been compacted down into the waste. The "effective" cover of a trench may include this zone.

Fourth, geophysical logs were run in a few $3 \frac{1}{2}$-inch pipes driven through the trenches (Prudic, 1979b). Generally, a peak in the gamma radiation corresponded to an interval of erratic resistance to penetration--about the same depth at which gas was detected in the $1 \frac{1}{4}$-inch pipes. In two pipes, however, small peaks appeared in the gamma log several feet above the depth at which the gamma log began to respond to radiation in the waste. These peaks probably reflect some waste that was incorporated into the cover as the trench was being covered.

Fifth, Prudic and Randall (1979, p. 865-867) observed that the barometric efficiency (ratio of change in trench-water level to change in atmospheric pressure) increased 8 to 10 percent when water rose above an altitude of $1376.5 \mathrm{ft}$ in trench 5. Such a change might be expected when rising water in trench 5 had filled most of the void space below the top of the waste. An average value of the cover thickness was derived for trench 5 from this information. Figures 3-5 are cross sections of trenches 5, 8, and 14 showing the position and depth of trench cover, zone of erratic resistance, and location of buried waste and drive pipes.

Table 1 lists the following data for most trenches: (1) average cover thickness as derived from topographic maps (this was considered a minimum value); (2) estimates of cover thickness where pipes were driven through the cover (minimum values are derived from resistance to penetration by drive pipes; maximum values are derived from the detection of gas and from geophysical logs); and (3) author's judgment as to average trench-cover thickness. From the computer program by Weeks (1978), sensitivity analyses of cover thickness indicate that the maximum error in calculated hydraulic conductivity due to uncertainty of cover thickness is about 50 percent. 
Table 1.--Estimates of cover thickness over selected low-level radioactive-waste burial trenches

[A11 values are in feet]

\begin{tabular}{|c|c|c|c|c|}
\hline \multirow[b]{2}{*}{$\begin{array}{l}\text { Trench } \\
\text { number }\end{array}$} & \multirow[b]{2}{*}{$\begin{array}{l}\text { Average cover thickness, } \\
\text { estimated from trench } \\
\text { design, nearby test } \\
\text { holes, and topographic- } \\
\text { map data }\end{array}$} & \multicolumn{2}{|c|}{$\begin{array}{l}\text { Estimated cover thickness near } \\
\text { pipes driven through the cover }\end{array}$} & \multirow[b]{2}{*}{$\begin{array}{l}\text { Average } \\
\text { effective } \\
\text { thickness } \\
\text { of cover } \\
\text { (author's } \\
\text { estimate) }\end{array}$} \\
\hline & & $\begin{array}{l}\text { (Only to } \\
\text { base of re- } \\
\text { worked till) }\end{array}$ & $\begin{array}{l}\text { Maximum } \\
\text { poorly perme-- } \\
\text { poole mixture } \\
\text { of till and } \\
\text { waste) }\end{array}$ & \\
\hline 2 & 6 & 6.5 & 13 & 10 \\
\hline 3 & 6 & 8 & 12 & 10 \\
\hline 4 & 6 & 8 & ${ }^{2} 10-16$ & 10 \\
\hline $1_{5}$ & 6 & $25-9$ & $27-15$ & 8 \\
\hline 8 & 9 & 13 & 15.5 & 11 \\
\hline 9 & 9 & 9 & 10 & 11 \\
\hline 10 & 9 & 13 & 18 & 11 \\
\hline 11 & 8 & 10 & 16 & 11 \\
\hline 12 & 8 & 9 & 13.5 & 11 \\
\hline 13 & 8 & 9 & 16 & 11 \\
\hline${ }_{14}$ & 7 & 8 & 9.5 & 9 \\
\hline
\end{tabular}

1 Thickness is less than at other trenches owing to east-west change in land-surface altitude. (See figs. 3 and 5.)

2 Range was obtained from more than one series of pipes driven through trench cover. (See Prudic, 1978 and 1979b.) 
EXPLANATION TO FIGURES 3-5

Slope of trench walls is drawn as depicted in a photograph of an open section of trench 14. Trench walls in figure 3 are to be shown 5 feet west of the trench center line (determined from trench monuments) as inferred from geophysical data.

Typical well or pipe driven into or through trench

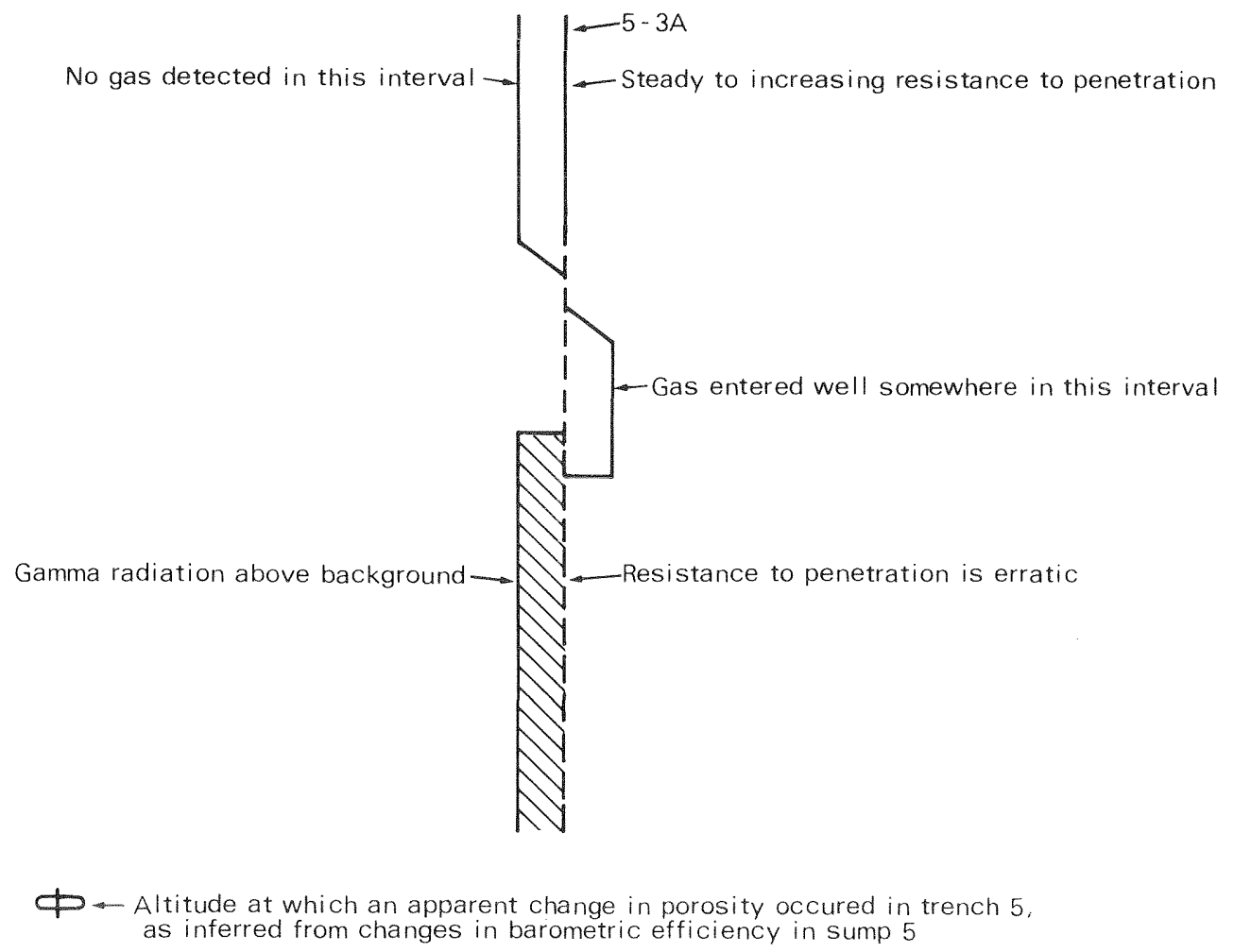




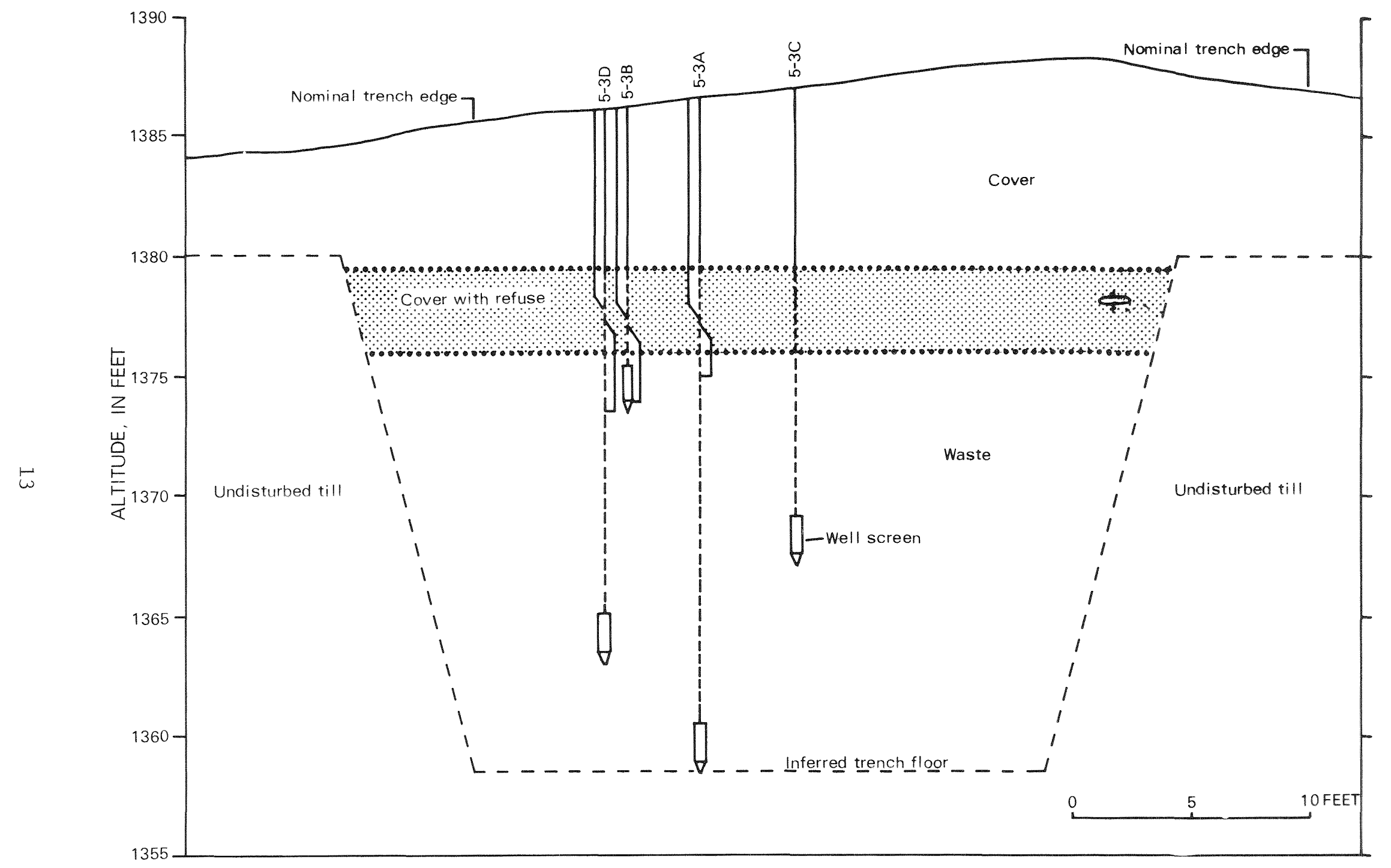

Figure 3.--Cross section of trench 5 at well series 5-3. Trench walls are drawn $5 \mathrm{ft}$ west of trench center line as inferred from geophysical data. 


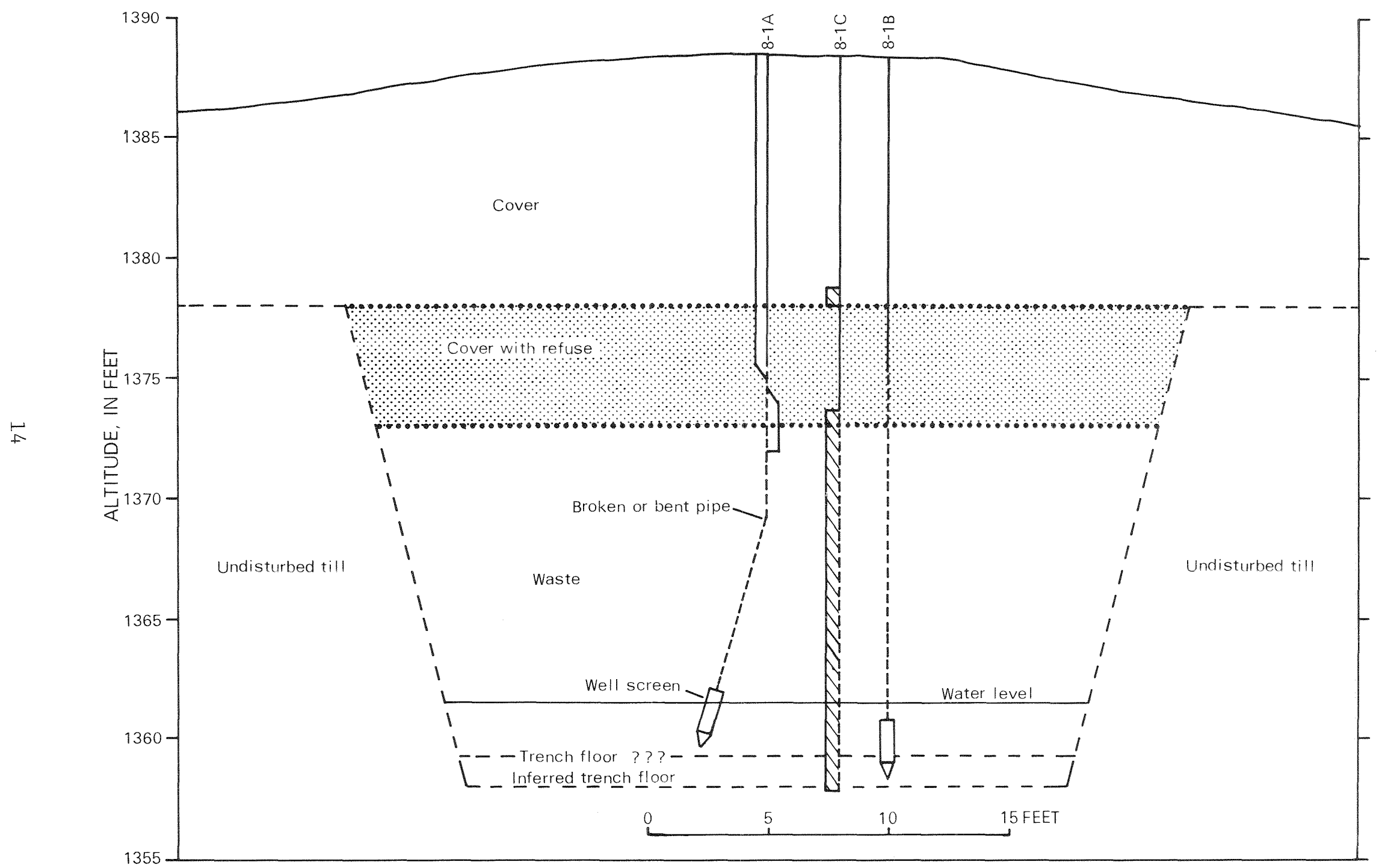

Figure 4.--Cross section of trench 8 at well series $8-1$. 


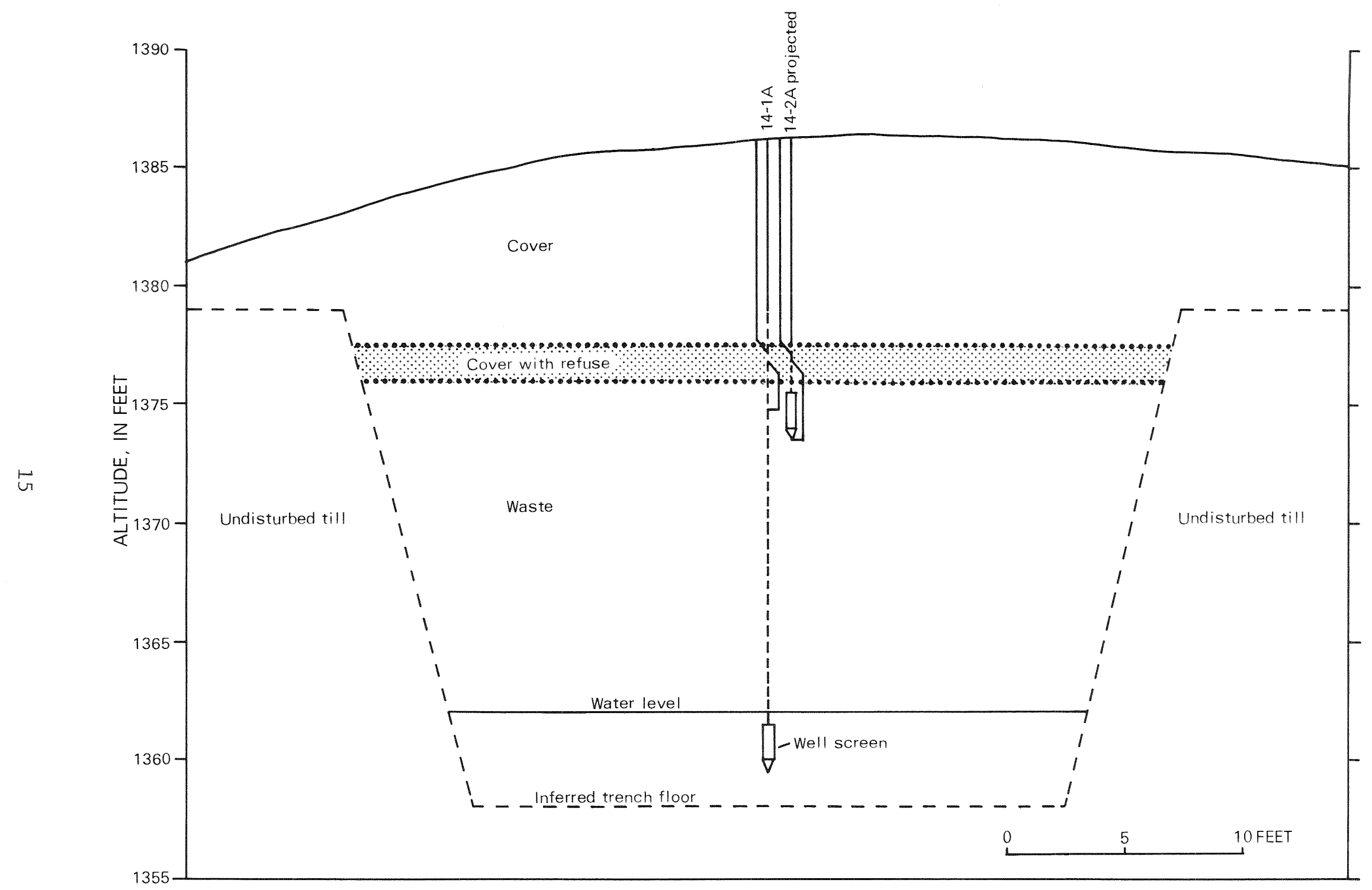

Figure 5.--Cross section of trench 14 at well I4-IA (well 14-2A projected). 


\section{Air-Filled Porosity of Covers}

The cover material is reworked clay-rich till that was excavated during trench construction. Undisturbed till at the site has an average porosity of 32 percent, as determined by laboratory tests of 30 core samples, but the airfilled porosity is dependent on the prevailing moisture content. Most pores (except close to land surface) probably remain saturated because (1) moist, plastic till has frequently been observed at shallow depth atop the trenches and elsewhere, and (2) laboratory tests on samples of the undisturbed till suggest only a 2-percent reduction in moisture content at a soil suction of 33 feet of water. However, numerous cracks in the cover have been observed both parallel and transverse to the trenches; these may be the principal avenues for water and air movement through the cover into the trenches (Prudic and Randa11, 1979, p. 865). The air-filled porosity of the cover was assumed to be the same as the effective porosity caused by these cracks.

The effective porosity of a fractured till in Manitoba, Canada, was estimated to be 0.02 percent (Grisak, 1975). The Canadian till is fractured throughout its thickness with numerous regularly spaced, narrow fractures (Grisak and Cherry, 1975, p. 28). However, the cracks in the trench covers at West Valley during the late summer and fall were commonly about an inch wide at land surface, and a steel tape was inserted into several fractures to depths of more than 2 feet. These cracks are several times larger than those observed in Canada. Therefore, the effective porosity and hence the air-filled porosity of the trench covers is probably greater than the 0.02 percent determined by Grisak. An estimate of 1 percent was used in this study.

To test the validity of the above estimate, sensitivity analyses of the air-filled porosity of the cover over trench 12 were done with the computer program by Weeks (1978) to estimate hydraulic conductivities from data collected in October 1977. A 30-fold increase in the air-filled porosity in the model resulted in a 15-percent change in the calculated hydraulic conductivity; thus, the calculated hydraulic conductivity was fairly insensitive to changes in the air-filled porosity of the cover. The 1-percent value used is therefore considered accurate enough for this study.

The reason that the air-filled porosity of the cover does not greatly affect the calculated cover hydraulic conductivity is that the lower layer (trench waste) has a high hydraulic conductivity and air-filled porosity that dampens any change caused by variation in the cover air-filled porosity. If the hydraulic conductivity and the air-filled porosity of the trench wastes approximated the cover properties, any changes in the air-filled porosity of the cover would have a greater effect.

\section{Thickness, Hydraulic Conductivity, and Air-Filled Porosity of Buried Waste}

The unsaturated thickness of the trench waste was determined from waterlevel measurements obtained monthly by the site operator (Nuclear Fuels Services, Inc.) and periodically by the U.S. Geological Survey. In general, the water surface within each trench is level, as determined from multiple wells in several trenches (Prudic, 1978). 
In general, the hydraulic conductivity of the wastes in the trenches is very high as inferred from data collected during the pumpout of water from several trenches (Prudic, 1978, p. 14) and is estimated to be more than 2,500 feet per day. This estimate is based on calculations from several trenches and was derived from Darcy's equation by determining: (1) the gradient between two points within a trench while water was pumped from it; (2) the percentage of trench water that moved between the two points; and (3) the area of the saturated cross section of each trench. The effective air-filled porosity was estimated by dividing the volume of water pumped out by the calculated volume of the trench from which the water was removed.

Sensitivity analysis of these properties was done with the same data and computer program that were used to evaluate air-fflled porosity of the cover over trench 12 . Changes in the hydraulic conductivity of the waste were shown to affect the calculated values of the cover only when the hydrauIic conductivity of the waste was less than 10 feet per day, whereby a threefold increase in the air-filled porosity of the trench resulted in a threefold increase in the cover hydraulic conductivity (fig. 6). Therefore, to determine hydraulic conductivity of the cover over a trench by this technique, accurate values of air-filled porosity of the waste must first be obtained, which may be a limiting factor in the usefulness of this technique. (If no values of air-filled porosity of the waste are available, a method described by Lu and Matuszek (1978) may be used to estimate the void volume. Their estimates for several trenches at the West Valley site are generally similar to porosity estimates obtained from the pumpout of trench water.)

\section{Kinematic Viscosity of Water and Dynamic Viscosity of Air}

The kinematic viscosity of water and the dynamic viscosity of air are functions of temperature (Daugherty and Franzini, 1965, p. 9). Although accurate values for these properties at various temperatures are needed to determine air permeability and hydraulic conductivity of the cover under varying climatic conditions (winter versus summer), viscosity values will most likely be the same in all trench covers at any given time. Therefore, the differences among hydraulic conductivities of different trench covers measured at the same time should not be a function of these properties.

In general, the kinematic viscosity of water changes more rapidly than the dynamic viscosity of air between a temperature change from $32^{\circ} \mathrm{F}$ to $80^{\circ} \mathrm{F}$; consequently, the calculated hydraulic conductivity of the trench cover is more sensitive to changes in the kinematic viscosity of water than to changes in the dynamic viscosity of air (fig. 7). For example, the increase in kinematic viscosity of water by a temperature increase from $32^{\circ} \mathrm{F}$ to $80^{\circ} \mathrm{F}$ would increase the estimated hydraulic conductivity of the cover by a factor of 2 , whereas the change in dynamic viscosity of air that would result from the same temperature rise would increase the estimated hydraulic conductivity of the cover by only 10 percent. However, the temperature of water and air moving through the cover probably do not vary by more than $20^{\circ} \mathrm{F}\left(40^{\circ} \mathrm{F}\right.$ to $\left.60^{\circ} \mathrm{F}\right)$ from winter to summer. Values of kinematic viscosity of water and dynamic viscosity of air were obtained from Daugherty and Franzini (1965, p. 557-558); hydraulic-conductivity values were calculated from an air and water temperature of $60^{\circ} \mathrm{F}$ during summer and $40^{\circ} \mathrm{F}$ during winter. 


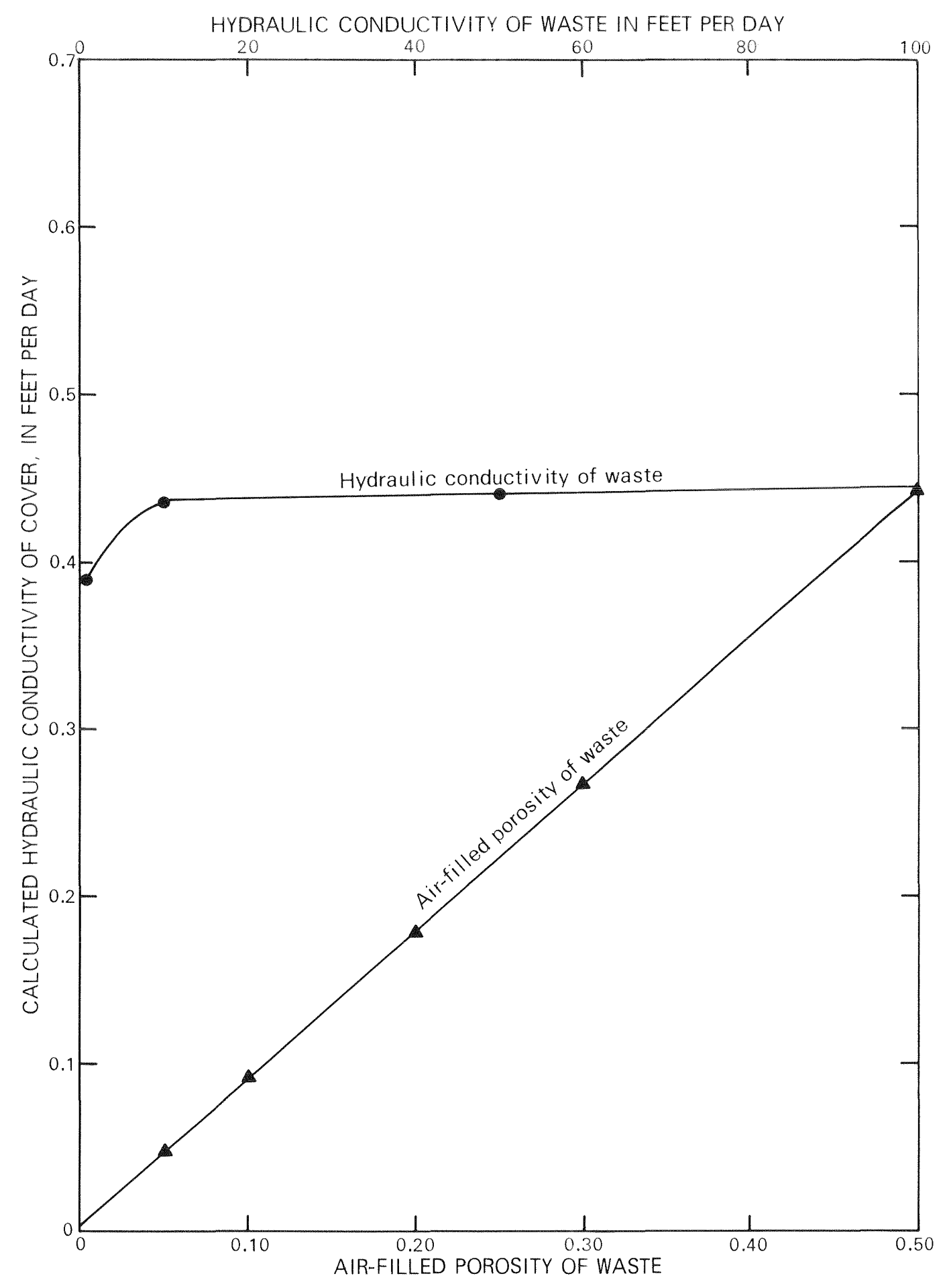

Figure 6.--Changes in calculated hydraulic conductivity of trench 12 cover in response to changes in hydraulic-conductivity and air-filled porosity values of the waste. 


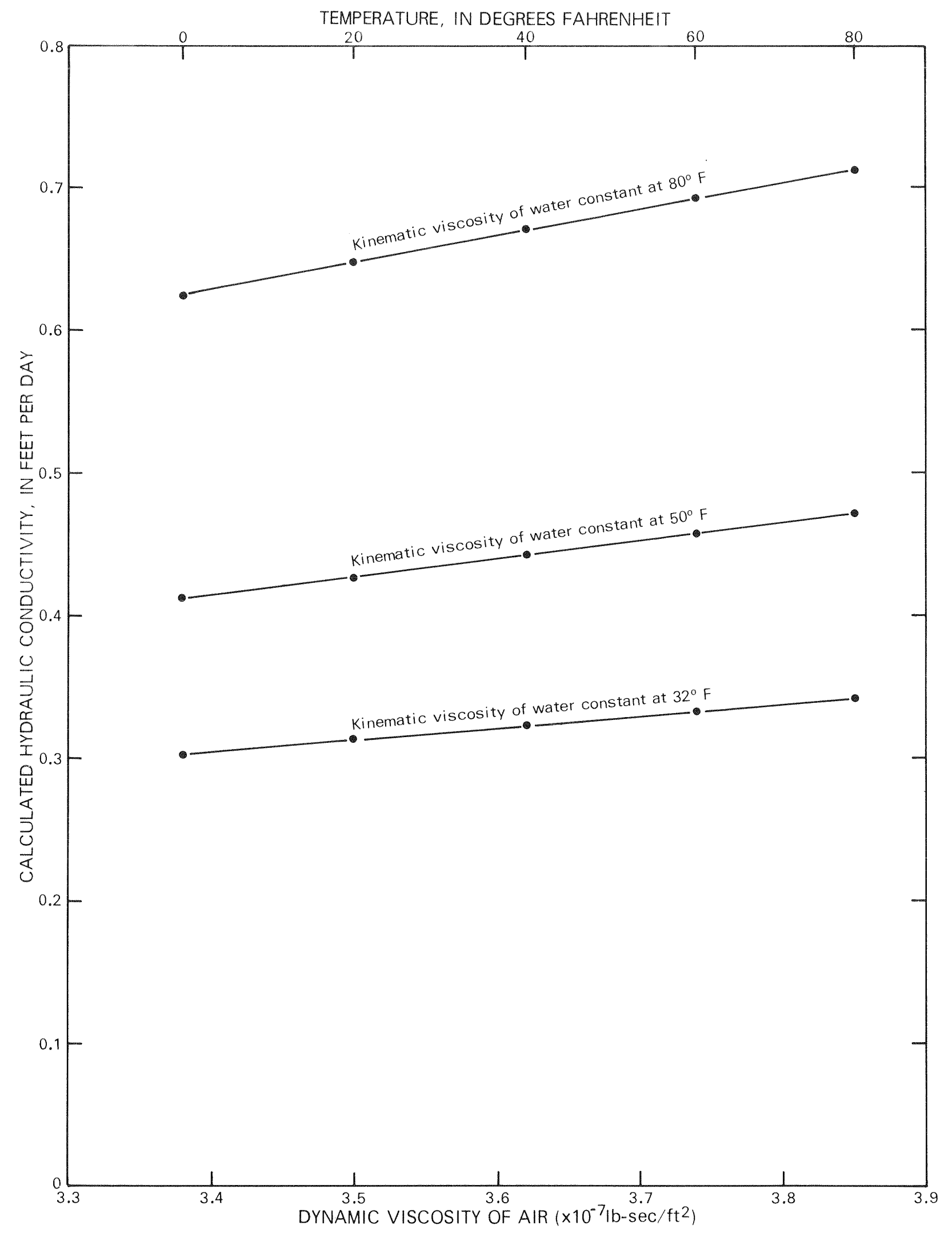

Figure 7.--Changes in calculated hydraulic conductivity of trench 12 cover in response to changes in dynamic viscosity of air and kinematic viscosity of water. 
Table 2 gives the estimates of each property used to calculate hydrau1ic conductivity of the waste in each trench studied. Values of air-filled porosity of waste determined by measuring the drop in pressure caused by removal of a known volume of gas (Lu and Matuszek, 1978) are included for comparison.

Table 2.--Values of trench-waste and trench-cover properties used to calculate hydraulic conductivity from air-pressure measurements

\begin{tabular}{|c|c|c|c|c|}
\hline \multirow[b]{2}{*}{$\begin{array}{l}\text { Trench } \\
\text { number }\end{array}$} & \multirow[b]{2}{*}{$\begin{array}{l}\text { Thickness } \\
\text { of cover } 1 \\
(\mathrm{ft})\end{array}$} & \multirow[b]{2}{*}{$\begin{array}{c}\text { Depth to trench } \\
\text { water } \\
(\mathrm{ft})\end{array}$} & \multicolumn{2}{|c|}{$\begin{array}{l}\text { Effective air-filled } \\
\text { porosity of waste } 2\end{array}$} \\
\hline & & & $\begin{array}{l}\text { Calculated } \\
\text { from } \\
\text { pumpout data }\end{array}$ & $\begin{array}{l}\text { Calculated } \\
\text { from Lu and } \\
\text { Matuszek } \\
\quad(1978)\end{array}$ \\
\hline 3 & 10 & ${ }^{3} 23-25$ & 0.17 & 0.23 \\
\hline 4 & 10 & ${ }^{3} 22-23$ & 0.19 & -- \\
\hline 5 & 8 & ${ }^{3} 25-29$ & 0.23 & 0.28 \\
\hline 8 & 11 & 28 & -- & 0.20 \\
\hline 9 & 11 & 27 & -- & 0.26 \\
\hline 11 & 11 & 27 & 0.27 & 0.29 \\
\hline 12 & 11 & 28 & 0.23 & 0.20 \\
\hline 14 & 9 & 24 & 0.37 & -- \\
\hline
\end{tabular}

Hydraulic data for all trenches:

Hydraulic conductivity of waste: $2,500 \mathrm{ft} / \mathrm{d}$

Effective air-filled porosity of cover: 0.01

Kinematic viscosity of trench water (summer): $1.58 \times 10-4 \mathrm{ft}^{2} / \mathrm{s}$

(winter): $1.46 \times 10-4 \mathrm{ft}^{2} / \mathrm{s}$

Dynamic viscosity of air (summer): $3.62 \times 10-7(1 \mathrm{~b}-\mathrm{s}) / \mathrm{ft}^{2}$

(winter): $3.74 \times 10-7(1 \mathrm{~b}-\mathrm{s}) / \mathrm{ft}^{2}$

1 Values from table 1.

2 Based on values from pumpout data. Air-filled porosity values

for trenches 8 and 9 were assumed to be similar to those for

trenches 11 and 12. A value of 0.25 was used to calculate

hydraulic conductivity of waste in these trenches.

3 Water levels lowered in October 1977. 


\section{Errors in Converting Air Permeability to Hydraulic Conductivity}

Weeks (1978, p. 4) has described in detail the sources of error in calculating hydraulic conductivity from air permeability in granular soils; these sources are summarized below:

1. If many pores are filled with water seasonally, the calculated intrinsic permeability (hence hydraulic conductivity) may be too small.

2. If pores are small, as in clay, intergranular permeability to gas at low pressures is greater than to water because of the Klinkenberg effect (K1 inkenberg, 1941).

3. If an appreciable change in moisture content occurs periodically, absorption of water by clay of particular cation chemistry may result in swel1ing and plugging of pores spaces (Johnston and Beeson, 1945).

At the burial site, observations and calculated permeability values suggest that water infiltrates mainly along cracks. Macroscopic fractures that conduct water into the trenches probably drain in a matter of hours (Prudic and Randal1, 1979, p. 865), and these openings would be too large for the Klinkenberg effect to be important.

Laboratory analyses of several unweathered till samples by X-ray diffraction (LaFleur, 1979, table 1) show that illite is the dominant clay mineral and that the percentage of a mixed-layered clay, such as montmorillonite, in till is low, suggesting that the till should swell or shrink but little during either wet or dry periods. However, the development of cracks in the trench covers during dry periods indicates that shrinking does occur and undoubtedly complicates the relationship between air permeability and water permeability. This relationship may also be affected by the transport of sediment into fractures by runoff, which could cause them to clog rapidly.

\section{RESULTS OF FIELD EXPERIMENTS}

Field measurements were made during July-August 1977, OctoberNovember 1977, February 1978, Apri1 1978, and July 1978. Estimates of hydraulic conductivity of the trench covers monitored are given in table 3 ; typical measurements from each period are plotted in figures 8-12. Computersimulated pressures matched measured values fairly closely, which indicates that the computer program provides a reasonable approximation of field conditions.

An independent but similar study was made by the Radiological Sciences Laboratory of the New York State Department of Health in 1977-78. The purpose of that study was to determine the amount of gas that could migrate through the trench cover from buried wastes ( $\mathrm{Lu}$ and Matuszek, 1978). Gas pressure in a trench was monitored while gas or trench water was pumped from another well, and the void volume, methane-production rates, and an expression for gas flow through the total area of the trench cover were calculated by a 
computer model. This expression was converted to air permeability and then to hydraulic conductivity by adjusting for trench area, estimated cover thickness, dynamic viscosity of air, and the kinematic viscosity of water (table 3 ). These values compare reasonably well with values calculated from air- and gaspressure measurements, as described in this report.

In general, estimated hydraulic conductivities are greatest in summer and lowest in winter and early spring (table 3); this pattern may be caused by a reduction in the size or number of fractures in the cover during the winter or by the sealing of fractures by a thin saturated-soil layer at the surface. During normal winters, the ground freezes to depths of about 2 feet, and perhaps to 4 feet under severe conditions. If the upper part of the covers were saturated or frozen, there should theoretically be no response in trench pressure to changes in atmospheric pressure. However, measurements taken in. February 1978 suggest that the covers were not entirely saturated or frozen; thus, some fractures apparently remain open in the cover during winter.

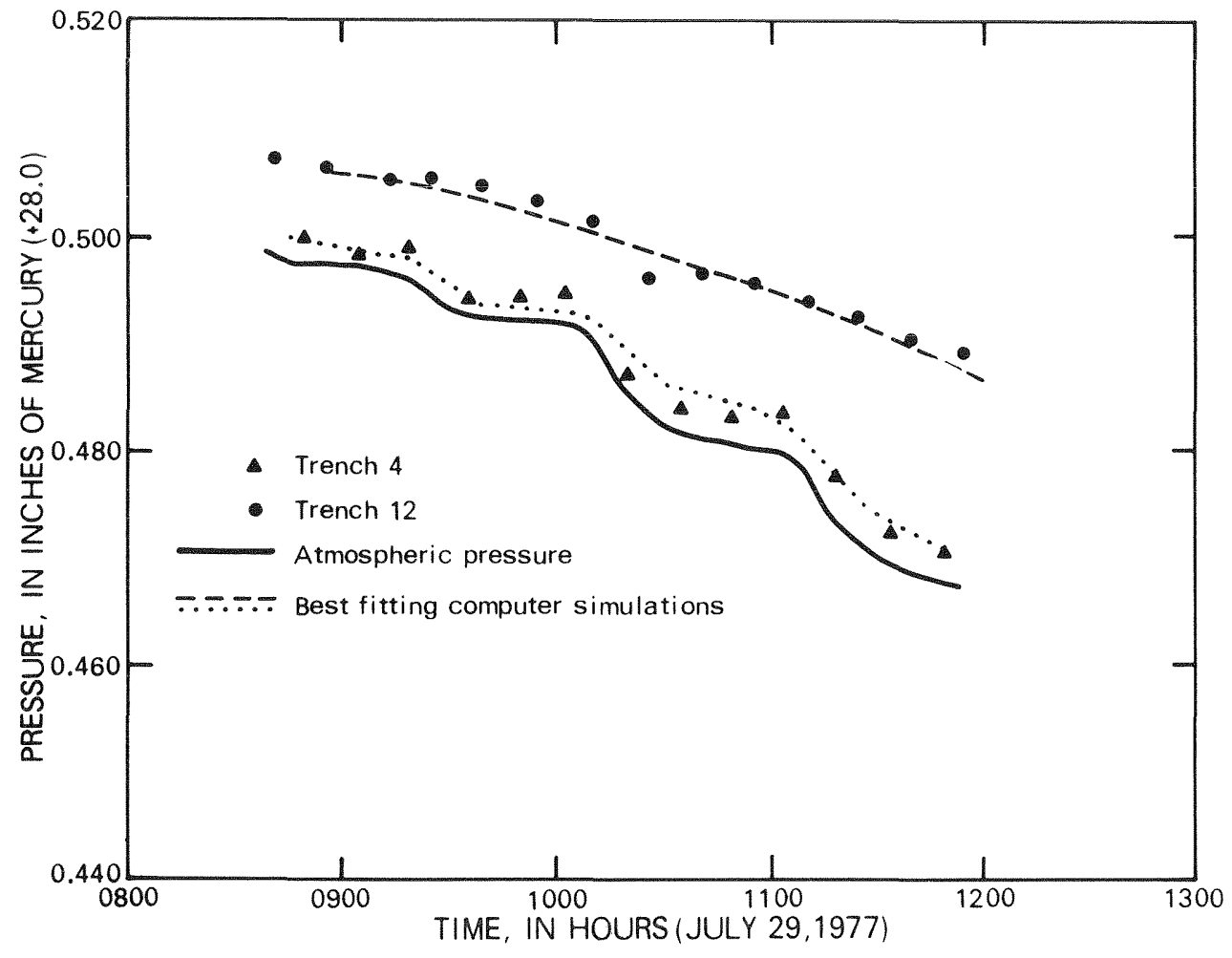

Figure 8.--Comparison of air pressures measured July 29, 1977, in trenches 4 and 12 with best fitting computer simulations. 


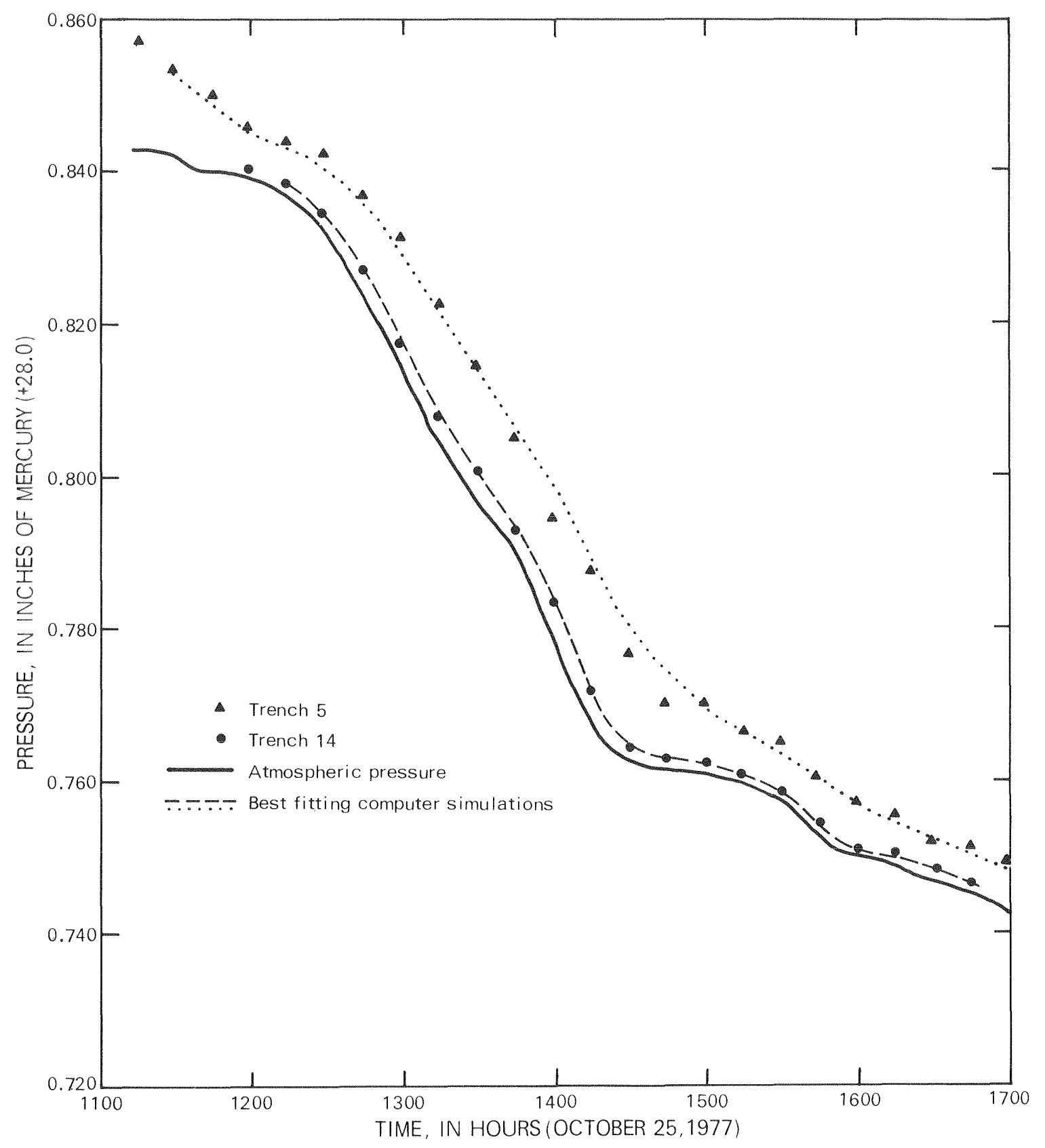

Figure 9.--Comparison of air pressures measured october 25, 1977, in trenches 5 and 14 with best fitting computer simulations. 


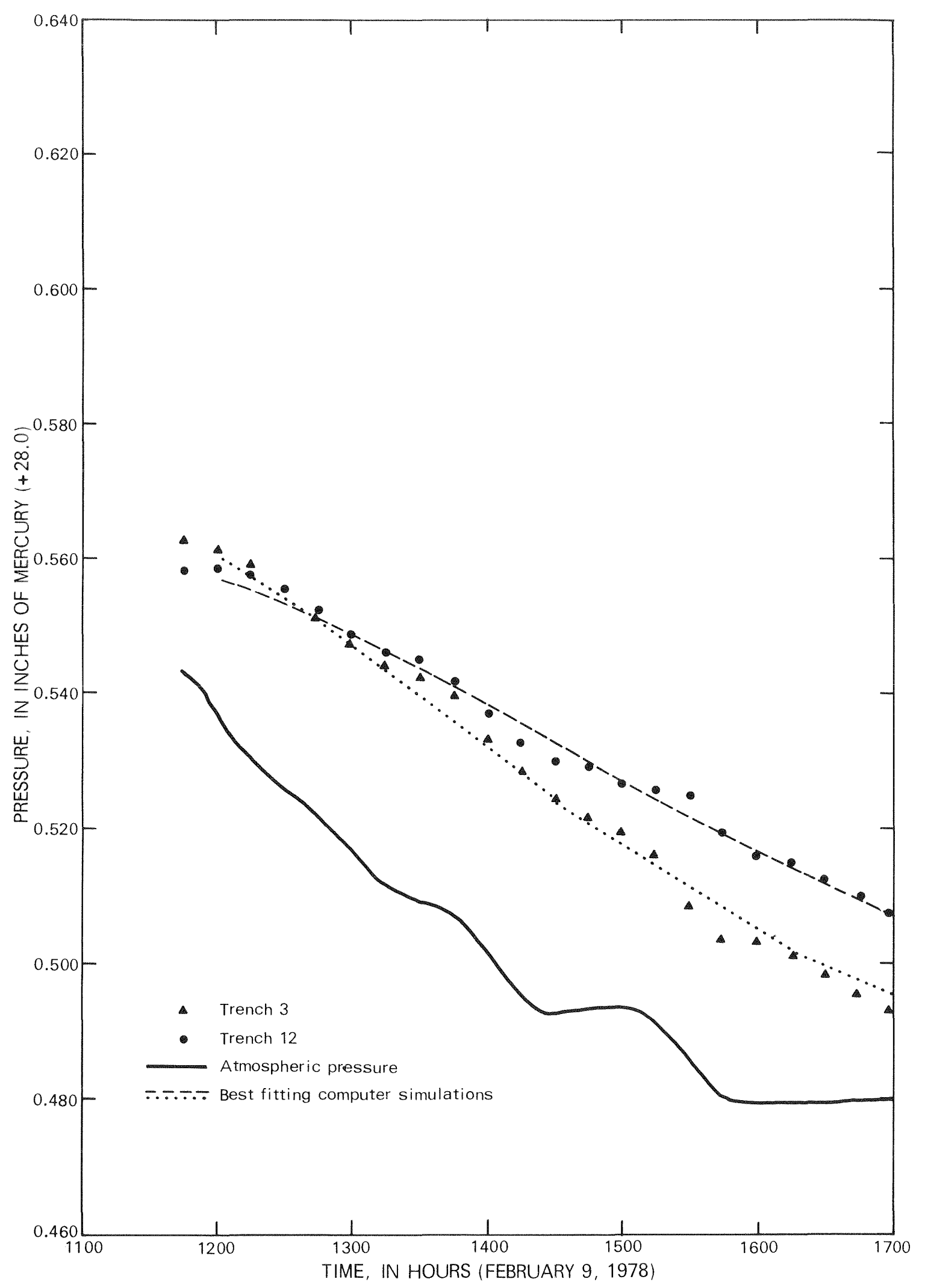

Figure 10.--Comparison of air pressures measured February 9, 1978, in trenches 3 and 12 with best fitting computer simulations. 


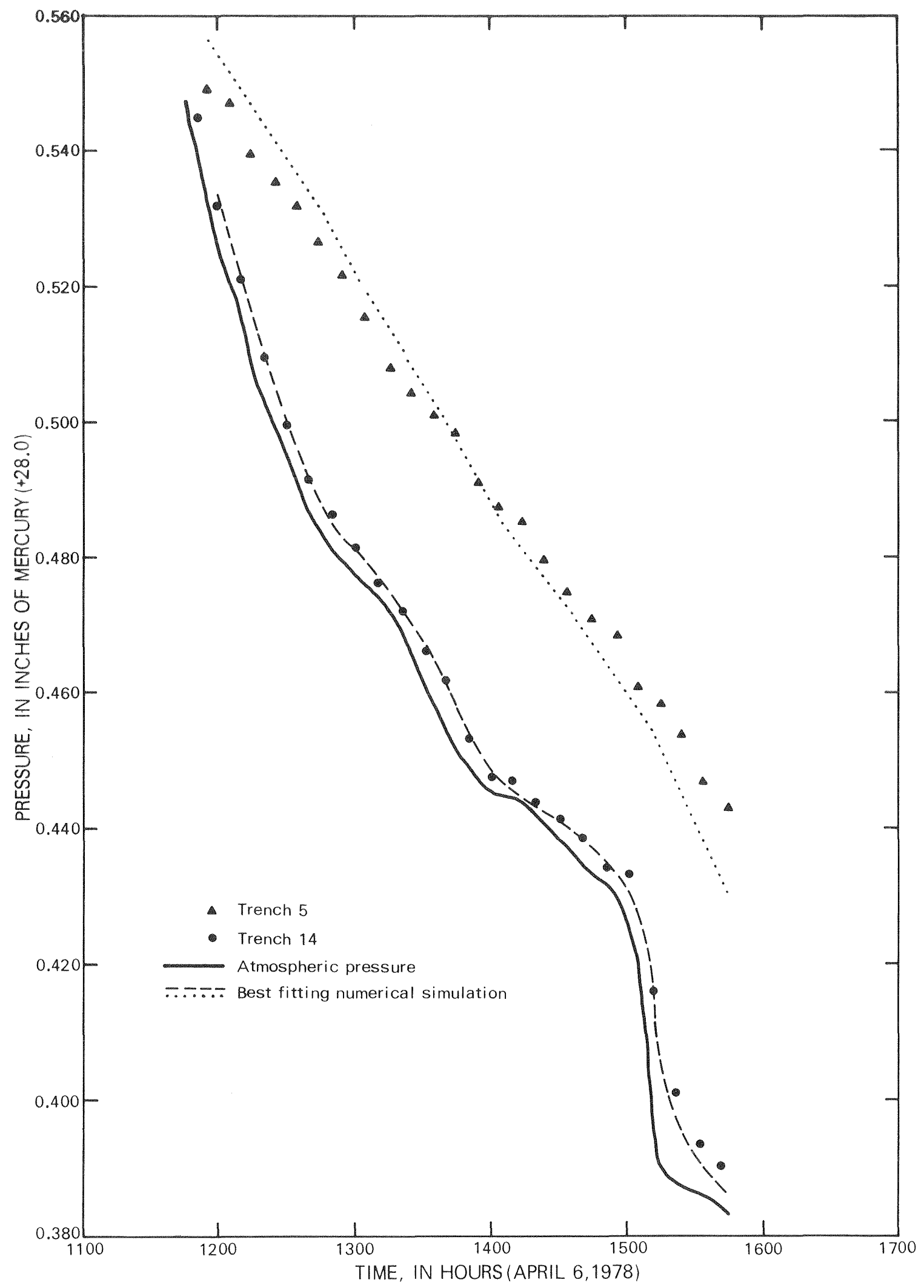

Figure 11.--Comparison of air pressures measured April 6, 1978, in trenches 4 and 14 to best fitting computer simulations. 


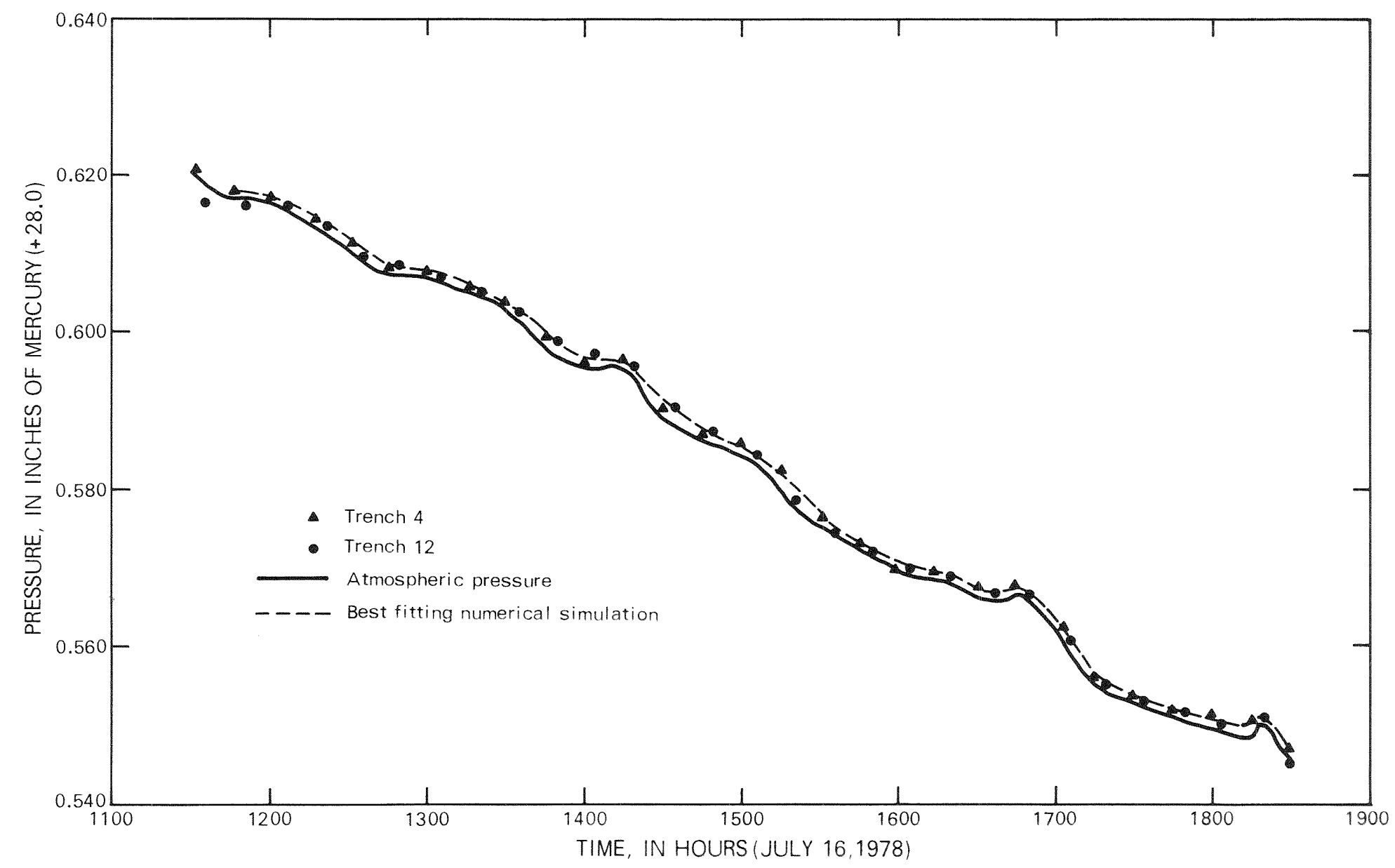

Figure 12.--Comparison of air pressures measured July 16, 1978, in trenches 4 and 12 to best fitting computer simulations. 
Table 3.--Hydraulic-conductivity values calculated from air-permeability values of selected trenches.

[A11 values are in feet per day]

\begin{tabular}{|c|c|c|c|c|c|c|c|c|c|}
\hline \multirow[b]{2}{*}{$\begin{array}{l}\text { Trench } \\
\text { number }\end{array}$} & \multicolumn{5}{|c|}{ Calculated from measurements made in this study } & \multicolumn{4}{|c|}{$\begin{array}{c}\text { Adapted from measurements and calculations } \\
\text { by Lu and Matuszek }(1978)^{1}\end{array}$} \\
\hline & $\begin{array}{c}\text { July-August } \\
1977 \\
\end{array}$ & $\begin{array}{l}\text { October- } \\
\text { November } \\
1977\end{array}$ & $\begin{array}{c}\text { February } \\
1978 \\
\end{array}$ & $\begin{array}{r}\text { April } \\
1978 \\
\end{array}$ & $\begin{array}{l}\text { July } \\
1978 \\
\end{array}$ & $\begin{array}{c}\text { October } \\
1977 \\
\end{array}$ & $\begin{array}{c}\text { February } \\
1978 \\
\end{array}$ & $\begin{array}{l}\text { Apri1 } \\
1978 \\
\end{array}$ & $\begin{array}{l}\text { July } \\
1978 \\
\end{array}$ \\
\hline 3 & $0.25-0.50$ & 0.41 & 0.12 & -- & -- & 0.68 & 0.15 & -- & 0.34 \\
\hline 4 & $1.0-2.3$ & -- & -- & $0.22-0.37$ & $3.7-3.9$ & -- & -- & -- & -- \\
\hline 5 & 1.8 & $0.69-0.88$ & 0.70 & -- & -- & 1.09 & 0.49 & 0.15 & 6.78 \\
\hline 8 & 0.41 & -- & -- & -- & -- & -- & 0.83 & 0.27 & 9.14 \\
\hline 9 & $0.20-0.22$ & -- & -- & -- & -- & -- & -- & 0.39 & -- \\
\hline 10 & -- & -- & -- & -- & -- & -- & -- & 0.46 & - \\
\hline 11 & -- & $0.17-0.33$ & -- & 0.25 & -- & -- & 0.32 & 0.34 & 9.79 \\
\hline 12 & $0.26-0.35$ & $0.23-0.30$ & 0.12 & -- & $11.6-12.7$ & -- & -- & 0.83 & 9.14 \\
\hline 14 & $>10$ & 5.5 & 0.29 & 4.6 & -- & -- & -- & -- & -- \\
\hline
\end{tabular}

1 Discussed in section "Results of field experiments," p. 21. 


\section{Hydraulic-Conductivity Differences Among Trenches}

In 1977, estimated trench-cover hydraulic conductivity was relatively low at trenches 3,8,9, 11, and 12; it was higher at trenches 4 and 5, and was highest at trench 14. The higher values for trenches 4 and 5 are consistent with the continued rise in water levels in these trenches since 1971 (Matuszek and others, 1976, p. 363; Prudic and Randa11, 1979, p. 862; Kelleher, 1979, p. 849), and the high value in trench 14 is consistent with the rise that has continued since that trench was completed in May 1975. (Trenches 5 and 14 were completed differently from the other trenches; normally the material excavated during the construction of a trench was piled onto the previous trench, but because trenches 5 and 14 were the last to be completed in each burial area, they did not receive this added material.)

Although the estimated hydraulic conductivity of the trench 3 cover was as low as estimates for the newer trenches in the south end, trench 3 had a history of rising water levels similar to those of trenches 4 and 5 (Matuszek and others, 1976, p. 363; Prudic and Randal1, 1979, p. 862; Kelleher, 1979, p. 849). The rise in trench 3 is noteworthy because it did not begin until the water level in trench 4 had exceeded it, whereupon it began to rise but at a slower rate. The water level in trench 3 has remained lower than in trench 4 (see fig. 6 in Prudic and Randa11, 1979); it is possible that the two trenches are hydraulically connected. Kelleher (1979, p. 843) states that on at least three occasions during excavation of the north trenches 3-5, a trench wall collapsed and exposed the waste of an adjacent trench, and, during excavation of trench 4, W. J. Kelleher (1979, oral commun.) noted an exposure of waste from trench 3. This, too, suggests a hydraulic connection between trenches 3 and 4 . Why the estimated cover hydraulic conductivity is lower than trench 4 is uncertain. Similar results were obtained by Lu and Matuszek (1978).

\section{Relation of Cracks in Covers to Changes in Hydraulic Conductivity}

The summer of 1978 was the dryest summer since 1975 and was almost certainly the dryest since 1971 (Prudic, 1979). Air permeability, hence estimated hydraulic conductivity, of the covers over trenches 4 and 12 was much higher in 1978 than in 1977, probably because of the 2-month dry period from the end of May through July 1978. Large cracks were observed over both the north and south trenches and were mapped in July 1978 (Dana and others, 1978). Often a steel tape could be shoved 1 to 3 feet down a crack before refusal, and the cracks were commonly 1 to 3 inches wide at the surface. The cracks are probably caused by shrinkage of the till cover during dry periods. Once they breach the cover or intersect fractures propagating upward by compaction and settlement of the waste, the movement of air and water is greatly accelerated, as suggested by the greater movement of air through the cover over trench 12 in July 1978 than in August 1977.

The study by Lu and Matuszek (1978) showed that the covers over trenches 5, 8, and 11 had increases in permeability in July 1978 that were similar to that of trench 12. This increase was followed by a water-level rise of more than 2 feet in trenches 11 and 14 and more than 5 feet in trenches 12 and 13 from September 1978 to April 1979. It was surprising that trenches 8-10 
showed no significant rise even though data obtained by Lu and Matuszek (1978) show the cover of trench 8 to have been as permeable as those of trenches 11 and 12 in July 1978. (See table 3.) One explanation is that the cracks were quickly sealed by some unknown process. It is also possible, although improbable, that water infiltrates into trench 8 then moves out through a permeable lens. Trench 8 was the only trench to show a decrease in water level after completion (see Prudic and Randa11, 1979, fig. 6), which could be interpreted as drainout of surface runoff trapped during the final stages of trench construction. About 4 feet of compacted cover was added to trenches 1-5 in August and September 1978; thus, no comparison can be made between the high estimates of cover hydraulic conductivity measured by air in trenches 4 and 5 during July 1978 and subsequent water-level behavior.

\section{Calculation of Hydraulic Conductivity from Water-Level Rise in Trenches}

Data and observations suggest that the predominant source of recharge to the trenches is infiltration of precipitation through the cover (Matuszek and others, 1976; Kelleher, 1979; Prudic and Randa11, 1979; and Prudic, 1979a). Therefore, the increase in water levels in a trench may be used to estimate the net volume of water that infiltrated through the cover during any given time period. The rate of infiltration through the cover may be calculated by dividing the volume of recharge to each trench by the total duration of intervals of significant precipitation during the selected time period. Trench-cover hydraulic conductivity may then be calculated from Darcy's Law:

$$
\mathrm{K}=\mathrm{Q} / \mathrm{IA}
$$

where $\quad \mathrm{K}=$ hydraulic conductivity of cover, ft/day;

$$
\begin{aligned}
& Q=\text { rate of infiltration, } \mathrm{ft}^{3} / \mathrm{day} ; \\
& \mathrm{A}=\text { trench area, } \mathrm{ft}^{2} ; \text { and } \\
& I=\text { vertical hydraulic gradient through cover, ft/ft. }
\end{aligned}
$$

In calculating the rate of infiltration, Q, for each trench studied, the following assumptions were made:

1. The increase in volume of water in the trench during each computation period was entirely from precipitation during that period-that is, the net flux of ground water into the trenches was negligible, and there was no change in storage within the unsaturated waste. Also, there was no hydraulic connection between trenches, contrary to the hypothesis in the preceding section concerning trenches 3 and 4 .

2. The rate of discharge through the trench floor and walls during the selected time period was calculated from Darcy's equation using a uniform hydraulic conductivity of 0.0001 feet per day for the till (average hydraulic conductivity from slug tests and laboratory tests), 
In addition, water moving through a fracture can move into the fine-grained clay interfracture blocks by capillary suction or be absorbed by the clays. Thus the hydraulic conductivity values of a fractured unsaturated medium calculated from water movement should be less than that calculated by air pressure measurements.

In calculating the hydraulic conductivity of the covers, the estimate of infiltration could be appreciably in error because (1) the specific yield of a trench may not be uniform throughout the thickness of the waste; (2) the area of the trench may not correspond to design dimensions of trenches for which pumping yields were not obtainable, and (3) the time during which infiltration occurs may not be accurately estimated. The amount of precipitation short of causing runoff into cracks varies with its intensity and with the length of previous rain-free periods; also, runoff that fills cracks may continue to drain downward through the lower part of the cover for some time after precipitation and runoff have ceased. However, none of the sources of error seems capable of distorting calculated hydraulic conductivity by more than a factor of about 2 .

For example, a change in the interval to include only those periods during which precipitation was more than 0.4 inches would cause, at most, a 25-percent net increase in the hydraulic conductivity value for the selected period. As a matter of interest, the increase in volume of water caused by a period of precipitation calculated for several trenches was compared to the total volume of precipitaion on the trench area. In trenches 3, 4, 5, and 14, the volume of water added to the trench was, at most, only 6 percent of the precipitation during any selected time period, whereas the lowest percentage was less than 1 percent (April 1978).

The estimated volume of water in a trench used to calculate the hydraulic conductivity of a cover could be in error if pumping water from the trench caused compaction of the waste and a corresponding reduction in the void volume in the trench. However, neither the data collected during successive pumping of water from trenches 3 and 5, nor estimates of void volume by air measurements ( $\mathrm{Lu}$ and Matuszek, 1978 and table 2) during and after the pumping of trenches 3 and 5 or from subsequent water-level trends (Prudic, 1979a, p. 4), support this possibility. Even if the voids were reduced 20 percent through compaction (far more than would be expected), the net effect would be to reduce the estimated cover hydraulic conductivity by no more than that amount.

In laboratory tests of samples containing similar percentages of clay-sized particles, air permeabilities commonly exceeded fresh-water permeabilities by 10 to 1,000 times (Katz and others, 1959, p. 43; Johnston and Beeson, 1945, p. 5, and Reeve, 1953, p. 327). These differences have been attributed to the percentage of clay-sized particles, the presence of swelling clay, and the blockage of pores by clay particles. 


\section{SUMMARY AND CONCLUSIONS}

Hydraulic conductivity of trench covers was calculated from measurements of the response of trench-gas pressure to fluctuations in atmospheric pressure. In 1977, the values were generally lower for trenches 8-13 than for trenches $3-5$ and 14 , which is consistent with the persistent rise of water levels through 1977 in the latter group of trenches. However, calculations of hydraulic conductivity of the covers from rates of water-1evel rise during the same time suggest a much lower hydraulic conductivity for all trench covers and a much greater difference between the two groups. Measurements of air pressure in trenches 11 and 12 in July 1978 indicate a large increase in hydraulic conductivity after 7 weeks of dry weather, which is consistent with the onset of persistent water-1eve1 rises in these trenches in mid-1978. Several lines of evidence suggest that movement of gas and water through the trench covers occurs largely along cracks rather than through intergranular pore spaces.

For those trenches in which sufficient seasonal data were collected, hydraulic conductivities calculated from air permeabilities of the covers were lower in the winter and early spring than in the summer and fall, probably because the clay-rich till swells enough to close most cracks during the winter or because the cracks are covered over with a thin layer of mud and ice during the winter and early spring. The fact that hydraulic-conductivity values calculated from air permeability are 100 to 1,000 times larger than those derived from infiltration rates may perhaps be explained by a sudden change in cover condition during precipitaion. For example, the high rates of infiltration through cracks could be reduced by swelling of the crack walls or by clogging of cracks by sediment washed in from the trench surface by runoff during periods of rainfall.

The high permeability of the cover over trench 8, as determined from air-pressure measurements in July 1978, seems inconsistent with the lack of significant water-level rise in this trench through mid-1979. One explanation is that, although the hydraulic conductivity was high initially, the cracks were quickly resealed by some unknown process. Another is that water level in trench 8 is controlled by outward seepage of water along a permeable lens; however, there is little independent evidence to support this speculation.

Although the hydraulic conductivity values calculated from air permeability are only relative and should not be taken as absolute values, the method seems promising for monitoring changes in the covers that may increase the flux of precipitation into the waste. It could also be used to monitor differences between trenches with different types of covers, or it could be used to estimate the movement of radioactive gases produced by the waste through the cover (Lu and Matuszek, 1978). 


\section{REFERENCES CITED}

Dana, R. H., Jr., Molello, S. A., Fakundiny, R. H., Matuszek, J. M. and Lu, A. H., 1978, Determination of retention of radioactive and stable nuclides by fractured rock and soil at West Valley, N.Y., phase II: New York State Geological Survey Open-File Report 78-2403, approx. 450 p.

Daugherty, R. L. and Franzini, J. B., 1965, Fluid mechanics with engineering applications: New York, McGraw-Hil1, 577 p.

Giardina, P. A., DeBonis, M. F., Eng, Jeanette, and Meyer, G. L., 1977, Summary report on the low-level radioactive waste burial site, West Valley, New York (1963-1975): U.S. Environmental Protection Agency, Rept. 902/4-77-010, 122 p.

Grisak, G. E., 1975, The fracture porosity of glacial till: Canadian Journal of Earth Sciences: v. 12, no. 3, p. 513-515.

Grisak, G. E., and Cherry, J. A., 1975, Hydrologic characteristics and response of fractured till and clay confining a shallow aquifer: Canadian Journal of Earth Sciences, v. 12, no. 1, p. 23-43.

Johnston, Norris, and Beeson, Carrol, 1945, Water permeability of reservoir sands: Petroleum Technology, v. 8, no. 3, p. 43-55.

Katz, D. L., and others, 1959, Handbook of natural gas engineering: New York, McGraw-Hill, 802 p.

Kelleher, W. J., 1979, Water problems at West Valley site, in Carter, M. W., Moghissi, A. A., and Kahn, Bernd, (eds.), Management of low-level radioactive waste, v. 2: New York, Pergamon Press, p. 843-851.

Klinkenberg, L. J., 1941, The permeability of porous media to liquids and gases: American Petroleum Institute Drilling and Production Practice, p. 200 .

LaFleur, R. G., 1979, Glacial geology and stratigraphy of Western New York Nuclear Service Center and Vicinity, Cattaraugus and Erie Counties. New York: U.S. Geological Survey Open-File Report 79-989, 17 p., 6 pls.

Lu, A. H. and Matuszek, J. M., 1978, Transport through a trench cover of gaseous tritiated compounds from buried radioactive wastes: International Symposium on the Behaviour of Tritium in the Environment: San Francisco, Calif., International Atomic Energy Agency, IAEA-SM-232/60, 22 p.

Matuszek, J. M., Strnisa, F. U., and Baxter, C. F., 1976, Radionuclide dynamics and health implications for the New York Nuclear Service Center's radioactive waste burial site: Vienna, Austria, International Atomic Energy Agency, IAEA-SM-207/59, p. 359-372. 


\section{REFERENCES CITED (Continued)}

Prudic, D. E., 1978, Installation of water- and gas-sampling wells in low-level radioactive-waste burial trenches, West Valley, New York: U.S. Geological Survey Open-File Report 78-718, 70 p.

1979a, Recharge to 1ow-1evel radioactive waste burial trenches 11 through 14, West Va1ley, New York: U.S. Geological Survey Open-File Report 79-990, 5 p.

1979b, Core sampling beneath low-leve1 radioactive-waste burial trenches, West Valley, Cattaraugus County, New York: U.S. Geological Survey Open-File Report 79-1532, 55 p.

Prudic, D. E., and Randa11, A. D., 1979, Ground-water hydrology and subsurface migration of radioisotopes at a low-level, solid radioactivewaste disposal site, West Valley, New York: in Carter, M. W., Moghissi, A. A. and Kahn, Bernd (eds.), Management of low-leve1 radioactive waste, v. 2: New York, Pergamon Press, p. 853-882.

Reeve, R. C., 1953, A method for determining the stability of soil structure based upon air and water permeability measurements: Soil Science Society of America, proceedings, v. 17, p. 324-329.

Weeks, E. P., 1978, Field determination of vertical permeability to air in the unsaturated zone: U.S. Geological Survey Professional Paper 1051, 41 p. 
